\title{
The T.V. in the Swimming Pool
}

\author{
by Richard Finn
}

A thesis submitted to Victoria University of Wellington in fulfilment of research requirements for the degree of Master of Arts in Creative Writing. 
Characters

DAVE

40

GEMMA

38 , his wife

SOPHIE

18 , their niece 
SET: Kitchen-dining-living room. Table. Sofa. A computer set-up on a desk. A stereo and a classic record player have pride-of-place on a sideboard. Lots of records.

Through French Doors up-stage centre can be seen lawn, bushes, children's play-gear including a paddling pool. A gravel path. It's dark inside and out.

Night, about 11.30pm. April 18, 2006, Wellington, N.Z.

Pre-show music would ideally be The Rolling Stones, recorded live.

\section{ACT ONE}

It's quiet, then sounds on a Baby Monitor. A baby waking, then crying, then settling down.

It's quiet again. Then the sweeping flash of headlights with the accompanying noise of a car pulling up. Doors open and close, off. A security light on the outside of the house clicks on. DAVE and GEMMA can be seen coming through the garden, towards the doors. Sound of taxi driving away.

GEMMA's at the door fiddling with getting keys out of bag. DAVE goes over to a bush, unzips. GEMMA turns, sees him 'watering the garden', shakes her head, unlocks the door and enters. She tosses her keys back in her bag, dumps the bag on the floor by a chair. Turns on a table lamp, and notices a duvet-covered lump on the sofa. She frowns and then sees a note on the bench. She crosses to kitchen area, and reads the note. Looks at the sofa lump. She starts to quietly get tea, etc out of cupboards. As she does this she glances off through the French doors.

DAVE is giving it a bit of Jagger out in the garden - singing, jiggling, as he finishes off and zips up. He struts on in.

DAVE $\quad$ '...but it's all right now! In fact it's a -'

GEMMA urgently "Ssssshes" him, finger to lips.

DAVE Huh?

GEMMA Shh!

GEMMA does the classic 'hands-in-prayer-position-at-side-of-inclined-head' "sleep" gesture, then points to the lump on the sofa. It moves slightly. 
DAVE tip-toes over towards sofa, looks over the back of it. Does a big "Oh!" face, and does big 'Who? What's going on here?' wide hands.

GEMMA does wavey 'Don't worry about it, I'Il explain later' hands. Goes back to cupboards.

DAVE shrugs, dumps his jacket on the computer desk and tip-toes in an exaggerated way away from the sofa.

GEMMA pops up from the cupboard under the bench with 2 cups, and puts them on the counter top. She forms her forefingers of both hands into a ' $T$ ' shape and raises eye-brows. It's a question.

DAVE stops his tip-toeing and attempts to hand-signal something back.

GEMMA looks, shakes her head. Frowns. Hand signals a 'C' shape. Another question. Gestures to the cups.

DAVE shakes his head, and does more incomprehensible hand signals.

GEMMA stares, lifts her shoulders. She doesn't get it.

DAVE does big tip toe through to kitchen area. Goes to the fridge, gets out a bottle. Holds it up and mouths "Beer" to her, with a bit of one-handed incomprehensible hand signalling.

GEMMA shakes her head, and turns back to the bench and fills the kettle as quietly as she can. Gets tea bag and cup.

After a swig or two DAVE puts the beer on the bench and tiptoes towards her turned-away body and grabs her arse. She gives a small shriek and drops the cup in the sink. It makes quite a noise. They both freeze and then stare towards the sofa.

Listening. Watching.

Nothing.

They relax and, smiling, GEMMA turns to him, but DAVE's on his way back to his beer, doing his big tiptoe.

GEMMA watches (he knows, he's performing for this audience), sighs, gets on with making her tea. Glances back towards him.

DAVE moves about half a dozen steps away, but then suddenly jerks to a stop, his hand goes to his chest. A shocked expression on his face. 
GEMMA gasps, looking very concerned.

DAVE reaches inside his jacket, brings out his cellphone. Shakes it at GEMMA to indicate that it's on 'vibrate'. Does the blowing out cheeks, patting chest mime that means "Gave me a fright".

GEMMA mouths an oath and goes back to tea-making.

DAVE looks at the text he's just received. Cracks up. GEMMA 'sshhes' him, pointing at sofa, frowning.

DAVE waves away her concerns 'whatever', points to the cellphone. Mouths "Steve".

GEMMA mouths "Who"?

DAVE mouths $\quad$ "Ssss...t...eeeeve".

GEMMA mouths "Who"?

DAVE mouths "Steve" again.

He then draws a big 'S' shape in the air.

GEMMA mouths "Ooh, Steve".

DAVE nods vigorously. Toothy smile, points at his cellphone, shakes head in admiration.

GEMMA frowns, 'yeah, I can imagine'.

DAVE brings the cellphone to her. She shakes her head. He's indicating 'go on, read it.' She sighs, and tries to read the text, but he doesn't hold it still enough, he's silently laughing. She takes it off him. Reads the text. Grimaces. Gives it back, shaking head.

DAVE mouths/mimes "What?" Open palms.

GEMMA makes the 'wanker' hand gesture.

DAVE cracks-up, nods, indicates that he's going to text that to Steve.

GEMMA mouths "No!"

DAVE starts texting. GEMMA rushes to him, tries to grab the phone, he holds it out 
of her reach. She hits him. He turns, huddles, as she continues to hit his back, and he continues to text.

DAVE turns, holds up cellphone in 'Ta-da, done it' gesture. GEMMA looks at him aghast/angry. They're very close together.

A moment, then she kisses him passionately, propelling him backwards.

He pushes her off and gestures to sofa.

They look. They listen.

Nothing.

She moves in again, smiling. He's not sure. Maybe this isn't such a good idea. She reaches into his shirt. Well, O.K., then. They lean in and, suddenly, a muffled sounding telephone starts to ring. Land line, not cell.

GEMMA rushes over to the wall phone. No handset there!

She frantically points this out to DAVE. He takes a moment to work out what she means, then starts to urgently look for the missing cordless handset, throwing cushions off the chairs, looking under coffee tables. All the while GEMMA is trying to get him to be quiet - Ssshhing and pointing.

DAVE finds the handset under his jacket on the computer desk, and quickly answers it.

DAVE (Whisper) Hello?... No, I don't have time to answer a few simple questions. But here's one for you. Why don't you get a life?

DAVE hangs it up.

The lump on the sofa moves. David does a 'yikes!' face. Indicates 'we'd better cool it'.

GEMMA thinks a moment. Smiles seductively. Goes to French Doors, opens them, turns and does the curling finger 'Come here' gesture. Backs out the doors.

DAVE's still unsure. Outside? He starts to go out after her. Stops. Grabs a cushion off of a chair. Nods to himself and goes out.

It's hard to see exactly what they are doing out there, it's all shadows and bits glimpsed through the door and windows, but after a moment we hear an almighty 'splash'. 
DAVE (off) SHIT!

GEMMA rushes in looking and listening towards the sofa.

Nothing.

DAVE staggers into doorway. He's drenched. And not happy.

GEMMA turns and sshhes and points. Sofa.

DAVE just looks at her. Then does the 'hands out to the side' here I am (all wet) gesture.

GEMMA looks, then bursts into barely suppressed laughter.

DAVE looks shocked at her reaction, then angry. He strides into the kitchen area, opens a drawer, and takes out a large knife. He turns and heads out the door.

Puzzled, GEMMA goes to the doorway. Through the window we see DAVE raise the knife and plunge it into something. He holds his victim up. There goes the paddling pool.

GEMMA is furious. She storms back inside, tosses her tea down the sink and reaches for a wine glass.

DAVE appears in the doorway with the knife held in his teeth. Hunter-gatherer mode. He gestures to the 'dead' paddling pool. Ah har! GEMMA refuses to look at him. He puts the knife down and swaggers up to her. She moves away. He dumps the 'dead' pool and swaggers to her. She moves away. He swaggers up to her. She raises both hands - stop! DAVE looks confused. He gestures to how wet he is. Gestures to the 'dead' paddling pool.

GEMMA shakes her head. She can't believe how insensitive he is.

He gestures to his groin.

Or how immature.

He does pelvic moves, not helping his case at all.

GEMMA's fuming. She goes and gets his beer off the kitchen bench. Holds it up.

DAVE nods. Yes, he'd like some beer.

GEMMA walks slowly right up to him. Takes a swig herself. Wipes her lips with the back of her hand. Grabs him by the belt of his trousers. DAVE smiles. Suddenly GEMMA pours the rest of the beer down the front of his trousers. 
DAVE stands there shock-faced.

GEMMA moves quickly away to kitchen. Somewhat satisfied.

DAVE's in a big puddle. He's confused, wet, and has a beer bottle in his belt. Not one of his better nights.

DAVE What. The. F-

GEMMA Ssshhh! Dave!

DAVE Gemma! I, look -

The duvet lump on the sofa moves.

GEMMA Oh, good one.

The duvet unfolds to reveal SOPHIE, late teens, still half asleep.

SOPHIE(Yawning) Oh, hiya.

GEMMA Hey Sophie, didn't mean to make such a racket.

She glares at DAVE.

SOPHIE 's raining? (Yawn) You're all wet.

GEMMA tosses DAVE a tea-towel.

GEMMA This is a nice surprise.

DAVE What am I supposed to do with this?

He gestures to the tea-towel. She ignores him.

GEMMA Haven't seen you in yonks. Since Dave's...?

DAVE Gemma?

SOPHIE Yeah. The birthday party.

DAVE This won't dry me.

SOPHIE Just thought. Say hi. 
DAVE I'm saturated.

GEMMA All good up your way?

DAVE I'm in a big puddle here.

SOPHIE The usual.

DAVE Gem!

GEMMA You are a big puddle.

SOPHIE Nothing to report.

GEMMA Get a towel. Not one of the good ones.

DAVE Which are the good ones?

GEMMA NOT the good ones I said.

DAVE I know what you said. How can I NOT get the good ones if I don't know which ones ARE the good ones!

GEMMA Can you keep your voice down? Want to wake the entire -

DAVE I just want a towel!

GEMMA glares, then heads for the door.

DAVE But not one of the good ones.

GEMMA stops in her tracks. Then continues and exits.

SOPHIE You guys are funny.

DAVE Yeah?

SOPHIE You kinda argue, but really you're lovin' each other when you do.

DAVE tries to dry himself.

SOPHIE(Yawns) Good night out in the big city?

DAVE Yeah. Rocking the 'Cake-tin'. 
SOPHIE Oh, right. The big concert. Cool.

DAVE It was beyond cool, it was...classic.

SOPHIE Uh huh

DAVE The legendary, greatest rock'n'roll band in the world playing the songs that made them famous. Right in front of me.

SOPHIE Man, you're really soaked.

DAVE Oh, you noticed.

SOPHIE laughs. GEMMA comes back in and tosses him a towel.

GEMMA Here. Try not to drip on Sophie.

SOPHIE It's fine.

GEMMA Used to guys dribbling at the sight of you, huh?

DAVE Gem.

SOPHIE (laughs) Doubt it!

GEMMA Oh, sure.

SOPHIE I wish.

GEMMA How is your love life? Seeing anyone?

SOPHIE Nah. Not now.

DAVE Jeeze, Gemma!

SOPHIE Um, look, actually -

GEMMA Just asking. Sorry, Sophie if, you know.

SOPHIE It's fine.

Slight pause. DAVE dries himself, GEMMA drinks her wine.

SOPHIE So. Um. Just thought l'd drop in. On my way through to, um, a mate's, but you weren't here - 
DAVE We went out before the thing.

GEMMA If we'd known.

SOPHIE No, it's fine. Still got my key. Fell asleep. But, um, guess l'd better get going. It's kinda late.

DAVE $\quad$...gonna go get changed...

DAVE starts to shuffle off.

GEMMA Call a taxi for Sophie first. Unless you want to crash here?

SOPHIE Oh...

DAVE makes a face 'what?' GEMMA ignores him. SOPHIE notices.

SOPHIE No. Thanks.

GEMMA Sure? It's no problem.

SOPHIE shakes her head. DAVE changes his shuffle direction and makes the call during the following.

SOPHIE Finally suckered into the 'classic' stuff, Auntie Gemma?

GEMMA 'Gemma', please. "Auntie" was cute once, but now it just makes me feel old.

SOPHIE 'K.

GEMMA And, no, l'm not. It's definitely a Dave thing.

DAVE calls over from phone.

DAVE You loved it!

GEMMA But, yeah, O.K., considering that they're all in their sixties.

SOPHIE No way.

GEMMA And on-stage for over two hours...

DAVE (on phone) Hi. Taxi from Karori to, um, what's that? 
GEMMA He's still a very sexy man.

DAVE (on phone) That right?

GEMMA Drink?

SOPHIE Nah, might make a cup of tea if there's time.

GEMMA gets a bottle out of the fridge, and flicks the kettle on. DAVE hangs up.

DAVE Who's a very sexy man? Me?

GEMMA What'd they say?

SOPHIE Mick Jagger.

DAVE Forty, forty-five minutes.

GEMMA What?!

DAVE Maybe an hour. The concert y'know.

GEMMA Did you call around?

DAVE Nah, be the same with all of 'em.

GEMMA Good one, Dave.

DAVE Not my fault they haven't got enough cars on.

SOPHIE Hey, l'll get a bus.

GEMMA You can't get a bus, it's not safe.

DAVE Look, it's O.K.

GEMMA It's not O.K.

DAVE I'll get changed and drive her.

SOPHIE It'll be fine, I can -

GEMMA You've been drinking! There'll be check points everywhere tonight just waiting for idiots like you. 
DAVE I'll go the back way. Where're your keys?

GEMMA Are you deliberately trying to upset me?

DAVE What?

GEMMA What sort of message are you sending Sophie?

SOPHIE It's cool, I'll just wait for the taxi. Have a cup of tea.

Gemma, you having this wine here?

GEMMA Dave, you just...grrrr! Thanks Sophie.

DAVE What?

GEMMA shakes her head. Gets given the wine she poured earlier and takes a large sip. DAVE's not sure what to do next. Indicates his wet clothes and points off. GEMMA ignores him. Takes another large gulp of her wine.

DAVE shuffles off, removing clothes as he does. He turns in the doorway to speak. GEMMA glares at him and he thinks better of it. He does a funny face to SOPHIE, who smiles. DAVE then exits.

SOPHIE makes her tea, choosing her moment.

SOPHIE Uncle David's so funny. I remember him when he baby sat us.

GEMMA Ah, yes, but what you found so appealing as a 7 year old, doesn't quite do it for me in a man turned 40.

SOPHIE Fair enough.

GEMMA Well, I think so, Sophie. Maybe not very rock'n'roll, but yeah, I think it's 'fair enough'.

SOPHIE Well, I-

DAVE (off) Where's my blue sweat shirt?

GEMMA Wait for it, 2,3,4 -

DAVE (off) Gemma?

GEMMA $\quad 6,7,8-$ 
DAVE (off) 's'O.K., found it!

GEMMA Hidden in your sweatshirt drawer. You were saying?

SOPHIE Well, yeah. I think that, um, well -

GEMMA You may want to think about re-filling my wine glass while you are thinking there young Sophie.

SOPHIE Sure. I think that, you and Uncle David, y'know, awesome. Wish I had, in my life, you know? And hey, what do I know? But you're happy, it's all good.

GEMMA smiles thinly and drinks from her refilled glass.

SOPHIE You'll make great parents -

GEMMA Tried that.

SOPHIE Not too late to try again.

DAVE (off) Hey, seen my, oh, don't worry, found it.

GEMMA (to self) ...fuck's sake...

SOPHIE And...Oh, what happened to the paddling pool?

GEMMA Dave, he...('hopeless' gesture)

SOPHIE Oh.

GEMMA Sorry, Sophie, he's an bloody idiot.

SOPHIE 's O.K. No biggie. And, and, your home, you know? I mean. It's...all...good. You know?

GEMMA Yeah. I'm so lucky.

SOPHIE Um.

GEMMA Look, I know how I come across. I'm a bitch.

SOPHIE What?

GEMMA Dave's such a nice guy, how'd he end up with her? 
SOPHIE No way!

GEMMA He's such fun, she's so sour.

SOPHIE Gemma -

GEMMA I used to be fun you know.

SOPHIE Didn't say that you weren't.

GEMMA He's destroyed the paddling pool in some sort of stupid, 'humorous' display and here I go again being a bitch I just can't help myself I'm a bitch.

SOPHIE Hey -

GEMMA Bitchy, bitchy, bitch.

SOPHIE HEY! It's fine about the pool. It's, you know -

GEMMA "All good"?

GEMMA drinks, SOPHIE considers.

SOPHIE Um, maybe I should go.

GEMMA No, sorry, look. Don't know where all that came from. Take no notice. Sorry.

SOPHIE 'S O.K.

GEMMA drinks. SOPHIE looks at her. Shivers. Wraps herself in the duvet.

SOPHIE You know what 'bitch' stands for?

'Babe In Total Control of Herself'.

GEMMA That's a good one.

GEMMA drinks, moody. Pulls herself out of it.

GEMMA How's school?

SOPHIE Thinking of dropping out.

GEMMA Oh? 
SOPHIE Might have to. Mmmm, I love this duvet, smells of talcum powder, and soap, and....love.

GEMMA Boy trouble?

SOPHIE Yeah, sort of. Boys and their bits.

GEMMA Ha! I love that!

SOPHIE Do they ever get over being boys? With bits?

DAVE enters in fresh clothes, humming/singing a Rolling Stones tune. He heads straight for the fridge. Gets a beer.

DAVE ...'do ya think the boy's insane? He's insane-ane-ane'...

Starts to open it, sees the two women looking at him.

DAVE What?

They laugh.

DAVE What?

GEMMA shakes her head, sips her wine. DAVE's not sure how to respond, so plunges on.

DAVE 'I know, it's only rock 'n' roll, but I like it. Like it. Yes I do.' Had a great time tonight, eh, Gemma?

GEMMA Mmmm.

DAVE That's her "I'm really excited" face.

GEMMA 'Ho, ho, ho', so funny.

DAVE She has a wide selection of faces, don't you, Gem?

GEMMA What's this face mean Dave?

DAVE So, in celebration of this significant event, I have, for you, a treat. I'm going to play a very special EP.

He goes over to the record player, and his well-ordered, extensive record collection. He carefully extracts a small record album. In a way that resembles a ritual, he puts it on during the following. (Finger tips only: remove, wipe, place, 
check, play, stare at cover.)

SOPHIE A...what?

GEMMA Oh Sophie, don't.

DAVE This! This is an EP Sophie. But not just any EP, no, no, no! This is a magic record! 'Five by Five'. Original issue, pristine condition. Released August, 1964. Special occasions

only.

SOPHIE A mini record?

GEMMA Exactly! A baby record!

He ignores her, moving into his own world.

DAVE

Recorded at the famous GEMMA Blah, blah,

fucking

Chess Studios, Chicago,

blah,

June 11, 1964. A slice

of classic R'n'B, recorded

blah, boring me and Sophie

by the future of rock'n'roll. to death, blah

12 minutes and 49 de blah...

seconds of music history.

SOPHIE Wow. Short record.

GEMMA That seems to last a lifetime.

DAVE Sometimes five tracks are all you need.

SOPHIE So, who's on it?

DAVE The Rolling Stones, Sophie! Very, very early -

GEMMA Dave.

SOPHIE Man, that's an old record player.

DAVE This baby, is a '72 Thorens TD125 Mkll turntable -

GEMMA Dave!

DAVE - with the TP 16 tonearm, anti-magnetic skate control - 
GEMMA She's not interested!

DAVE - belt-driven -

GEMMA DAVE!

DAVE O.K! (He glares at GEMMA, then) Remember the day I got the Thorens, Gem? Remember that day?

GEMMA What?

DAVE $\quad$ Forget it. Here we go, their Satanic Majesties when they were still kinda innocent...

He carefully brings the stylus arm down on the record.

And...

The power goes out. Moonlight through the windows.

SOPHIE Wooo!

DAVE Powercut.

GEMMA You think? Where are the matches?

DAVE Um.

SOPHIE l've got a lighter.

DAVE Hang on.

DAVE's feeling his way into the kitchen. Bashes into something.

DAVE Ow, shit!

SOPHIE flicks her lighter on.

GEMMA Thanks Sophie.

GEMMA reaches for a candle and lights it from SOPHIE's lighter.

DAVE finds a torch.

SOPHIE This is cool. We should tell ghost stories.

DAVE Hope that didn't damage... 
He examines the stereo by torchlight. The women light more candles.

GEMMA Narrow escape there Sophie. Divine interference.

SOPHIE Ha, yeah.

DAVE You mean 'intervention'.

GEMMA What?

DAVE The phrase is 'divine intervention'.

He fiddles with the stereo. She just looks at him.

SOPHIE Lucky this didn't happen during the concert.

DAVE Yeah. It was a great show. Took me back.

GEMMA You're seriously comparing that concert to you and your band? 35,000 people at the stadium versus 6 mates in a student bar!

DAVE I meant -

GEMMA Oh, come on!

SOPHIE You in a band Uncle David?

DAVE I meant it's been a while -

SOPHIE When?

GEMMA Try twenty years.

DAVE I meant, a while since we'd been to a rock concert.

GEMMA and DAVE eyeball each other.

SOPHIE Like at 'varsity?

DAVE We used to play the Student Union, a few bars.

SOPHIE What'd you play?

DAVE Bass. You know my mate Steve? You met him at my party. 
SOPHIE Yeah -

DAVE Drums. We weren't that good, but we were loud.

GEMMA Jeezus, l'll say.

DAVE What we lacked in talent, we made up for in volume!

SOPHIE Oh, you saw him play Gemma. That how you two met?

DAVE/GEMMA Yeah/No.

GEMMA I came to that gig well after we first met.

DAVE $\quad$ Fell for that whole rock star thing I had goin' on!

GEMMA Rock star thing my ar -

SOPHIE Gemma. You were a thingie!

DAVE She was! A what?

GEMMA What?

SOPHIE A groupie!

DAVE A groupie! You're right!

GEMMA Dreaming.

DAVE She was, Sophie, she came to all the gigs, down the front.

GEMMA Oh, whatever Dave.

DAVE It's true!

SOPHIE What was his band like?

DAVE Great.

GEMMA Terrible. But they thought they were great.

DAVE We were. Kind of.

GEMMA They acted like rock stars, and just assumed anyone 
who accidentally stumbled into their gig was a groupie -

DAVE It was no accident that you -

GEMMA I went into the wrong -

DAVE You knew perfectly -

They both turn to SOPHIE, occasionally speaking at the same time.
GEMMA
I had no idea that his band was on that night
DAVE She knew that I and I certainly did not go was playing that there looking for Dave night.
Davidson who I was told
was totally in love with
himself, which was true and -
DAVE So she came to have a perve at the bass player 'cos she'd been told he was a bit of a spunk and it was -
GEMMA A total turn-off.
DAVE Love at first sight.
$\begin{array}{llrl}\text { GEMMA So there was no way } & \text { DAVE } \begin{array}{l}\text { So, absolutely, } \\ \text { that I was a - }\end{array}\end{array}$
GEMMA/DAVE Groupie!

They look 'daggers' at each other, then she smirks and he falls about laughing.

SOPHIE Met at a gig. Very rock ' $n$ ' roll.

DAVE She was stalking me.

GEMMA Rock star fantasy.

DAVE's lifting the E.P. off the turntable. As he completes this, the lights come back on.

DAVE Hey, there we go.

GEMMA Great. Gonna make some toast.

She's up and into the kitchen area. He's wiping the E.P. and putting it back in 
its sleeve.

SOPHIE Sounds like you two had fun.

DAVE All going in the book.

GEMMA Oh, christ, The Book!

SOPHIE Yeah?

GEMMA We're yet to see any of it.

He pats the p.c. monitor.

DAVE It's all in here.

GEMMA How many years you been writing it now Dave?

She starts to go off.

DAVE Can't rush these things.

GEMMA Keep an eye on my toast.

DAVE Groupie!

GEMMA exits, giving him the finger as she goes. Smiling, DAVE watches her, then turns back to see SOPHIE watching him.

SOPHIE A book huh? 'bout you and your band...

DAVE Based on. You know. What could've happened.

SOPHIE Like what?

DAVE Fame, fortune, fans, and a spectacular rock star death.

SOPHIE You die?

DAVE Spectacularly! None of that choking on your own vomit stuff.

SOPHIE Uh huh.

DAVE Explosions and drama and world-wide grief. Haven't quite got that bit figured out yet. 
Slightly awkward pause.

DAVE Any suggestions?

SOPHIE About death? Pretty much study it at school.

DAVE Really?

SOPHIE Death 101. Katherine Mansfield, Sylvia Plath.

DAVE Right, right. Frida ...Eyebrow.

SOPHIE Out with a bang, huh? Suicide?

DAVE (sing/speaks)'Suicide is painless, it brings on many changes'

SOPHIE looks quizzically at him.

DAVE Old song, before your, forget it, um, no, possibly a tragic accident. 'Live fast, die young. Leave a good-looking corpse'

SOPHIE Uh, huh.

DAVE Jimi H., James D., Jim M., um...lan Curtis.

She clearly doesn't know these names. He plunges on.

DAVE Kinda attractive. Getting out early.

SOPHIE Yeah?

DAVE(sing/speaks) "Things they do look awful cold, hope I die before I get old."

SOPHIE You're not that old, Uncle David.

DAVE Thanks a lot.

SOPHIE Jokes.

Another slightly awkward pause. DAVE glances off to where GEMMA exited, then back to see SOPHIE studying him.

SOPHIE $\quad$...the secret life of Uncle David... 
He picks up the paddling pool, examines the knife wound.

SOPHIE Do you miss it? Playing in a band?

DAVE Hell yeah.

SOPHIE Get back into it.

DAVE That was then.

SOPHIE But if you miss it.

DAVE Mmm. I'm not sure what it is I miss. You know? A memory of what actually happened, or some mixture of drunken stories and stoned "if only's". Reckon I can glue this.

He looks through drawers, finds and fiddles with 'superglue' and the pool during the following. He glances at her, she smiles.

SOPHIE Drunken stories huh?

DAVE You wouldn't know anything about that would you, young Sophie? It's all Happy Pills with you lot eh?

SOPHIE just smiles.

DAVE It was a very cool time. Standing on a beer-crate stage, making loud noises, seeing people enjoying what you were doing.

SOPHIE That'd be awesome.

DAVE We were just O.K. But that was enough to occasionally be... bloody brilliant. There were times when I reckon I kinda knew what it felt like. Just a taste of what it's like for those guys on stage tonight.

SOPHIE Still play your bass?

DAVE Not for years. Hold these edges apart while I put the glue on?

SOPHIE You should. 
DAVE Get the old band together again, hit the road?

SOPHIE How cool would that be! Get some more groupies.

DAVE Might be a bit of a struggle to get those, these days.

SOPHIE You never know.

They do gluing stuff for a bit, then...

DAVE Maybe you could be one.

She's close, holding the pool.

SOPHIE Maybe.

Slight pause.

DAVE Traditionally, you know, groupie rules state that they go for the lead singer first, then the lead guitarist, and then down the line.

SOPHIE Down to the bass player?

DAVE Well, there was one band member below that.

SOPHIE Guess you get what you can.

DAVE Don't think your dad would be all that keen.

SOPHIE Sex. Drugs. Rock ' $n$ ' roll.

DAVE And a spectacular death.

SOPHIE Who gives shit what dad thinks. If you wanted me to, I would.

He looks at her. She looks at him. It's a loaded moment.

DAVE Um, look Sophie, you're a sweet kid, but -

SOPHIE I'm not a kid David.

DAVE Right.

SOPHIE I'm a consenting adult. 
DAVE Uh huh. Just. Look, I, listen, I don't actually need any groupies, thanks all the same.

SOPHIE Then why'd you ask me to?

DAVE I was joking. I do that. Drives Gemma crazy.

SOPHIE What if I told her.

DAVE Sophie.

SOPHIE I won't though.

DAVE Listen...

He takes her hand.

GEMMA (off) Someone check my toast?

SOPHIE Our secret, David. You and me.

DAVE Soph -

GEMMA (off) Hello?

DAVE Not going to happen.

GEMMA (off) Dave!

DAVE(calling to off) What?

GEMMA (off) $\quad \underline{\text { Toast! }}$

DAVE(calling to off) No thanks.

SOPHIE Dumb idea. Why the hell would you want to.

DAVE It's not that. It's -

GEMMA (entering) Dave, what are you doing?

He quickly lets go of SOPHIE's hand.

DAVE Nothing. What do you mean?

GEMMA Not a trick question. My toast? 
SOPHIE Uncle David's looking for new groupies for his band.

GEMMA Christ, that's sad, Dave.

SOPHIE You should hold auditions.

GEMMA You a starter then Soph?

SOPHIE Definitely.

GEMMA There you go Dave, Sophie'll be your groupie.

SOPHIE Might crash here after all if that's still O.K?

SOPHIE moves over and flicks through the records. DAVE turns and shakes his head at GEMMA, who frowns at him.

GEMMA 'Course. I'll give big bro a call...

GEMMA makes the call in the kitchen during the following. Over by the stereo, DAVE talks to SOPHIE in an angry whisper.

DAVE What's going on here Sophie?

SOPHIE I don't know. I like you. I get a bit nuts late at night. Too much caffeine. Hormones. l'm sorry, Uncle David. Being immature. Sorry.

DAVE $\quad$...no, I shouldn't've, you know...

He picks up the pool.

GEMMA(on phone) Bob. It's me.

SOPHIE I, um, I saw that you've still got the room set up.

She nods to offstage.

GEMMA(on phone) No, everything's fine.

DAVE Not my idea. Gemma's clinging to...

GEMMA(on phone) Sophie's here, spending the night.

SOPHIE Must be hard. 
DAVE

Been two years.

GEMMA(on phone) Well, I don't know about that, but it's no problem.

DAVE fiddles with the pool.

SOPHIE Still.

DAVE Got to move on sometime.

GEMMA(on phone) l'll check with Dave, but Saturday sounds fine.

SOPHIE Seems a waste, you know?

He looks at her.

SOPHIE You'll make a great dad.

She holds his gaze. But it's a vulnerable young girl that's looking at him. He frowns. His cellphone goes off. He gets a fright and fumbles one-handedly for it. SOPHIE, watching him, smiles. GEMMA looks over from her conversation on the phone. He tosses the pool at SOPHIE. She catches it, laughing.

DAVE Shit! That's the...second time... hello?

GEMMA(on phone) What time?

DAVE (on cell) Steve mate...Nah, nah, still up, still buzzing, Sophie's dropped by....wasn't it just? Yeah.

He sees GEMMA looking over at him. He draws a 'S' shape in the air and mouths "Steve". GEMMA gives him a wide-eyed "Really?" look. He nods, oblivious.

DAVE (on cell) ...listen, look, ah, tomorrow, you wanna grab a...?

Great. Yeah. Exactly! ...I know! Listen, listen, you

still got your kit?

GEMMA(on phone) O.K. Hang on...

DAVE (on cell) ...Where? Can you - ? Ow!

GEMMA has whacked him out the way with the phone to wave it at SOPHIE.

GEMMA Your dad wants to talk to you 
DAVE (on cell) Just Gemma beating me up. 'As usual', yeah. What's that?

GEMMA 'Ho, ho, ho'. Sophie?

DAVE Soph. Steve wants to say 'hi'.

He waves the cell at SOPHIE. GEMMA waves the other phone.

SOPHIE Gotta go pee. I'll text 'em.

She exits. DAVE and GEMMA shrug, and talk into their phones.

DAVE (on cell) ....said she'll text. GEMMA(on phone) ...said she'll text. Nah, great idea... Talk to you later ' $\mathrm{K}$, Later. 'bye.

They hang up. The toaster has popped. GEMMA goes to it.

GEMMA Shit, I hate this toaster...

She struggles to get her toast out, turning it upside down, shaking it. DAVE stands there, nodding, smiling to himself. GEMMA sees this.

GEMMA Don't show off in front of Sophie, it's embarrassing.

DAVE I'm not.

She's struggling with the toaster.

GEMMA I can't believe you did that to his pool.

DAVE I've fixed it.

GEMMA I'm just asking you to act your age.

DAVE I am.

GEMMA A 40 year old man trying to act like a teenager.

DAVE Jeesus...

GEMMA Just because you've suddenly got an audience -

DAVE Listen to yourself. 
GEMMA Just calm down. Can you do that? For me?

Pause.

DAVE Sure.

GEMMA Thank you.

Pause.

GEMMA Sorry. It's not you.

Pause. They look at each other.

GEMMA I hear him.

DAVE What?

GEMMA At night. On that monitor.

She nods at the Baby Monitor on the shelf.

GEMMA I go into his room. Where the other monitor is.

DAVE And?

GEMMA No one's there Dave.

DAVE You're hearing things.

GEMMA I hear him crying out for me.

DAVE Come on, Gem.

GEMMA Listen!

They do.

GEMMA Am I going mad?

DAVE No.

GEMMA He's...crying!

DAVE Gemma, he's not. 
GEMMA Then why do I hear him? Listen.

DAVE It's static. It's nothing.

GEMMA Let's go into his room.

DAVE Why?

GEMMA See if I'm really mad.

DAVE You are! You're a nut bar!

GEMMA Help me.

DAVE I'm not looking in an empty room. That's me helping you.

GEMMA I hear him!

DAVE I don't!

They stare at each other.

GEMMA You feel anything?

DAVE Why are you so fucking angry all the time?

GEMMA I'm angry at you Dave! I'm incredibly pissed off because you won't join me in my anger.

DAVE You think that screaming and shouting is the only way to react? Your way?

GEMMA You don't cry. You don't do anything!

DAVE There's no room! There's only room for your grief in this house.

GEMMA Fuck you.

DAVE My way just doesn't rate. Eh Gemma? I'm not bouncing off the ceiling like you so obviously I don't care as much.

GEMMA I hate you.

DAVE Big fucking deal. 
They both stand there, slightly shell-shocked.

GEMMA We going to get through this Dave?

Pause.

DAVE $\quad$...'course we are.

With an effort, they move on. He finishes off the bottle of wine into a glass. She turns to the toaster.

GEMMA So...What did he want? Steve. (To the toaster:) Come on...

DAVE passes her the glass.

She goes to a drawer, gets a knife out, goes back to the toaster. He's looking for another bottle of wine.

GEMMA He, um, seeing anyone?

DAVE Was. Don't think it worked out - Shit, GEMMA!

He launches himself across the kitchen bench and rips a plug out of a wall socket.

She stands there with the knife in one hand about to plunge it into the toaster she holds in the other. He points this out with a gesture.

DAVE Trying to kill yourself? It's still plugged in!

SOPHIE stands, looking on, in the doorway.

SOPHIE Wooo, yeah, that's really dangerous.

DAVE She always does that.

GEMMA Don't exaggerate.

DAVE 'What sort of message are you sending Sophie?'.

GEEMA gives him a 'you wanker' look.

DAVE Going to get another bottle to celebrate.

SOPHIE Celebrate what?

DAVE (as he exits) Steve and I are putting the band back together. 
He goes off. GEMMA gapes. SOPHIE sits on the floor and fiddles with the paddling pool.

SOPHIE ....see if I can...blow this up.... where's the....

GEMMA (to self) ....so sick of this...

SOPHIE Mmm?

GEMMA sits wearily on the sofa. SOPHIE blows into the pool.

SOPHIE $\quad$...ffffffffffffffffff...you O.K?...fffffffffffffffffff...

GEMMA Just tired. Can't sleep.

SOPHIE There's...fffffffff...pills for that...ffffff...these days...ffffff

GEMMA Got some.

SOPHIE Then...ffffffffffff...take - oh god.

She leaps up, runs to the kitchen sink, and throws up.

GEMMA Wooo, Sophie!

She's up and at SOPHIE's side, giving her a glass of water.

SOPHIE Ooooooo, god...

GEMMA Here...drink...

SOPHIE throws up some more.

SOPHIE Ooooo...sorry 'bout this....

GEMMA S'O.K.

SOPHIE Making bit of a mess.

GEMMA God. Don't worry ‘bout it -

SOPHIE Must have...eaten...something. Ooooo...

GEMMA Yep, most probably. Unless you're pregnant 'ho, ho, h- ‘ 
SOPHIE just looks at her.

GEMMA Oh.

SOPHIE throws up some more.

GEMMA Oh, wow.

SOPHIE Ooooooohhh god.

GEMMA Oh Sophie, that's, that's, what? Good? Bad?

SOPHIE looks at her, then throws up some more.

GEMMA O.K...Do your Mum and Dad know?

SOPHIE No-one knows! I don't know! Please don’t say anything.

GEMMA Well -

SOPHIE They'd kill me, oooo...

She dry retches.

SOPHIE I can't be, l'm still at school. It's not...

GEMMA Right.

They look at each other.

SOPHIE Will you...

GEMMA What?

SOPHIE Will you...take it?

GEMMA What!

SOPHIE This baby.

GEMMA Sophie, that's -

SOPHIE You lost yours. You can't have any more.

GEMMA My god. What are you saying? 
SOPHIE

GEMMA

SOPHIE

GEMMA

SOPHIE

GEMMA

SOPHIE

GEMMA

SOPHIE

GEMMA

SOPHIE

GEMMA

SOPHIE

GEMMA

SOPHIE
Here's another chance.

That why you suddenly turned up here tonight?

See, it all works out.

It's not that simple.

You want one, I don't.

There's Dave -

This is best for everyone. It's best for the baby.

Look, Sophie -

l'll kill it.

What?

I'll get rid of it.

Sophie.

Tomorrow. l've made the appointment.

You don't know what you're saying.

You give me your word you'll take it, and I won't go. I'll see it through. Up to you.

GEMMA stares at her. Tears form, trickle down her cheeks.

GEMMA This is not fair.

SOPHIE After what happened, I thought you'd be pleased.

GEMMA So unfair.

SOPHIE I thought you'd have wanted it.

GEMMA Oh, Sophie. I don't even know if Dave and I are gonna -

SOPHIE Don't worry about it.

GEMMA Sophie, I - 
SOPHIE Look, I gotta go.

She starts to gather up her stuff.

GEMMA Please don't.

SOPHIE Yeah. I got to, um, get going, to, um...

GEMMA Alright.

SOPHIE Yeah, say "bye" to -

GEMMA ALRIGHT.

They look at each other.

SOPHIE You sure?

GEMMA No. Yes. I don't know. Yes.

SOPHIE I need you to -

GEMMA YES. My...you have my word.

They look at each other. A moment.

SOPHIE O.K. then.

GEMMA shakes her head.

GEMMA My god.

GEMMA stares at her, tears running down her face.

SOPHIE Thank you.

They hug. GEMMA shakes her head, crying.

GEMMA Thank...you.

DAVE sees this as he enters, carrying wine.

DAVE For what?

They turn to him. 
DAVE Oh, what is this?

GEMMA, weeping, and SOPHIE, smiling.

DAVE (to SOPHIE) What have you said to her?

SOPHIE I-

DAVE Look Gemma, nothing happened. Just...groupie jokes.

GEMMA What are you talking about?

SOPHIE Weren't talking about groupies David.

DAVE Is it the pool? I've fixed it!

His cell phone rings.

GEMMA The pool -

DAVE Hang on. Hello?

DAVE answers the call on his cell. GEMMA turns to SOPHIE.

GEMMA Bear with me, this is, um.

DAVE (on cell) Mate! What's that?

GEMMA Tricky.

DAVE (on cell) No, she said she'll text you.

GEMMA Dave. Hang up.

DAVE (on cell) I don't know.

He points to SOPHIE, then back to his cell phone. SOPHIE shakes her head.

GEMMA Now Dave, this is important.

DAVE (on cell) Look, l've gotta go. What?

GEMMA Dave!

DAVE (on cell) Right. 
GEMMA Dave, switch that bloody thing off and listen to me for a minute.

DAVE hangs up the cellphone, but makes a connection.

DAVE Oh. Is it Steve and the band idea?

GEMMA No, it's definitely not Steve.

DAVE It's Steve.

GEMMA No.

DAVE What is it with you and him?

GEMMA What? Nothing.

DAVE O.K, it's dumb, the band won't be opening for the Stones anytime soon -

GEMMA You THINK?

DAVE But -

GEMMA Wow! Newsflash!

DAVE O.K. Take it easy.

GEMMA Let's chuck it all out Dave!

DAVE What?

GEMMA All that old stuff. Yeah! The scratched records you never play, the old valve amp that doesn't go, that old turntable, the books and magazines you've read a thousand times. Stuff you've had in boxes since school. Boxes and boxes of it. Chuck it all out, start afresh.

DAVE That's, that's all valuable stuff! That Thoren TD -

GEMMA O.K, sell it!

DAVE No, I love that turntable.

SOPHIE Buy it all new on c.d. All the cleaned-up re-issues! 
GEMMA Better still, discover new music. Write a different book.

DAVE No.

GEMMA Get rid of it all. All that PAST. Most of which isn't even your past!

DAVE No. It's...research. I need it.

GEMMA We NEED to try something different. Something new.

DAVE We're fine.

GEMMA It's just STUFF! It doesn't MATTER!

DAVE It matters to ME!

GEMMA More than me?

DAVE YES!...sort of. Sometimes.

They look at each other. Long moment.

DAVE Sorry.

She stares at him, he looks away.

GEMMA Hope you and your turntable will be very happy together.

Fighting tears, she starts to exit.

SOPHIE Gemma, you need to tell -

GEMMA Don't! You. Dare.

She glares at her, and then exits.

DAVE stands there. Sees SOPHIE looking at him. He moves to his stereo, and tidies his records for a bit.

DAVE Tell me.

SOPHIE What? 
DAVE What she doesn't want you to.

SOPHIE Um.

DAVE What's the deal here Sophie?

SOPHIE Um.

DAVE It's not just my stuff. There's something else going on.

He stops, a realisation.

DAVE Is it, is there...someone else?

SOPHIE Um.

DAVE Oh my god.

He still has his cellphone in his hand. He stares at it with mounting horror.

DAVE Is it, it's not...

SOPHIE Um.

DAVE It is, isn't it? That bastard.

SOPHIE Steve?Yeah.

DAVE When? Tell me!

SOPHIE Um. About nine weeks ago, you know, your party?

DAVE My birthday party?

SOPHIE That was the night.

DAVE That BASTARD!

He sinks to the floor. Or a chair.

DAVE God, I can't breathe...

SOPHIE Here, blow into this.

She passes him the pool. He blows. 
SOPHIE Honestly David, it's going to be O.K.

He blows into the pool.

SOPHIE 'member when I got this?

DAVE Knew there was an issue, but never thought she'd...Christ.

SOPHIE Blow. There. Good one.

The pool is finished, fully inflated, sitting in the middle of the room.

They stare at it.

DAVE It's my fault isn't it? Have to been desperate and drunk to turn to him. I need a drink.

DAVE gets up goes to the fridge, gets out a six-pack of beer. Comes and sits back down by the pool. He opens beers and passes one to SOPHIE.

SOPHIE Oh. Um.

She doesn't want it. He doesn't notice and swigs on his. She thinks, looks about, then empties her beer into the paddling pool.

DAVE How long have you known 'bout this?

SOPHIE It's a, um, very recent development.

He shakes his head, dwelling on this. Passes her another beer. Which she empties into the pool.

DAVE Who else knows?

SOPHIE No one.

DAVE $\quad$...can't believe...

Distractedly, he empties his beer into the pool as well. SOPHIE grabs another can and continues filling the pool. Passes one to DAVE.

SOPHIE Tommy's pool's looking water-tight.

DAVE Told her l'd fix it.

Empties his beer into the pool. 
DAVE She just had to give me a chance.

SOPHIE plays with a can, stirring the beer in the pool.

SOPHIE How'd it happen? The night Tommy...?

He looks at her. Looks away.

DAVE He went to sleep and just didn't wake up.

SOPHIE Didn't cry or anything?

Pause.

DAVE $\quad$...not a sound.

Pause.

SOPHIE Crazy.

DAVE And then some.

Enter GEMMA with a box. It's marked "Dave's".

GEMMA Stinks of beer in here.

SOPHIE Leak test.

She indicates the pool, and the empty beer cans.

DAVE What's with the box?

GEMMA You're going, Dave. Take your stuff with you.

GEMMA dumps the box by the door, and starts to go back off again.

DAVE l'm going?

GEMMA I'm kicking you out Dave! You, and all your boxes of important stuff that you so desperately need.

DAVE Gemma.

GEMMA You've made your choice. So stuff you and stuff your stuff!

She continues to move off. 
SOPHIE Um. Gemma.

GEMMA It's O.K. We'll work something out.

She continues to move off.

DAVE I know. I know what this is about.

GEMMA stops, turns, frowns at SOPHIE.

DAVE Sophie didn't say anything. Doesn't take a rocket scientist to figure out what's going on here.

GEMMA So -

DAVE So, you're right. I don't need all this stuff. But listen.

Me leaving is not the answer. We need to face this thing together.

GEMMA 'Thing'?

DAVE What you've done is wrong, but we all make mistakes. You should've talked to me first.

GEMMA Well, O.K., but -

DAVE I needed to be there to talk to. You're right.

GEMMA $\quad$ I -

DAVE Totally! It's just stuff I hide behind.

GEMMA Well, yes -

DAVE The music, the book.

He indicates his records. Then the p.c. monitor.

DAVE Not important!

GEMMA O.K...?

DAVE So, listen. I..... forgive you.

GEMMA What? 
SOPHIE bursts out laughing.

GEMMA I...Sophie, what's going on?

SOPHIE Well, he kinda worked out that there is, or could be, 'someone else' in your life -

DAVE I drove you to it didn't I?

GEMMA stares uncomprehendingly at him.

DAVE No one needs to go, Gemma.

His cellphone rings. He grabs it out of his pocket. Holds it up in front of GEMMA, and dramatically drops it into the paddling pool. It makes a last strangled ring, then stops.

DAVE See what I mean?

GEMMA No, not really...

They both look down at the pool.

DAVE Yeah. Me neither.

GEMMA fishes the phone out.

GEMMA Probably just drowned Steve.

DAVE Good job. Bastard.

SOPHIE Chucking stuff into the swimming pool. Very rock star.

GEMMA Look Dave. I don't know what's going on with you here, but-

SOPHIE Should really be a T.V. though.

DAVE I get it now Gemma. I, I've been wrapped up in this 60's fantasy - records, books, the music, the musicians, I love it. But. It's not real.

GEMMA Dave -

DAVE I put on a record. I play that music, and I GO. I just disappear into the sounds and the words and the attitude. 
And I love it. But it's not the here and now. Hell, it's not even THEN. It's my fantasy 'then'. I don't even play some records because I don't want to spoil my memory of them, I love them too much.

GEMMA Dave, I need someone, here, now. This era.

DAVE

Yes. I get it. This is my fault. I drove you into another man's arms.

GEMMA You think I'm having an affair.

DAVE My god, what a night.

GEMMA That's what this is about?

DAVE Gemma. No more secrets.

GEMMA Dave. We're...

A glance at SOPHIE.

GEMMA We're expecting.

DAVE $\quad$ Yes. $\underline{\text { O.K.... what? }}$

GEMMA Pregnant. We think.

SOPHIE Pregnant. Definitely.

DAVE Huh?

SOPHIE The 'someone else' Dave. Get it?

Both women smile widely. They reach out and hold each other's hands. DAVE frowns, trying to work out what's going on.

DAVE So...Steve?

GEMMA Steve?

DAVE Oh, I see. This is all a big JOKE!

GEMMA Look, there's something we need to talk about.

He goes over to the stereo and grabs his headphones. Selects a record. 
SOPHIE You need to hear this Uncle David.

DAVE Actually, Sophie, I don't.

GEMMA takes a big breath.

GEMMA Dave, we're going to have a baby.

He stares. Then turns away, gritting his teeth.

DAVE Bullshit.

SOPHIE It's true! Listen to her -

DAVE This is low, Gemma, even for you. Really, really low.

GEMMA I'm not kidding. We're going to have $a b-$

DAVE We both know that's not possible Gemma. We both know what the doctors said. Not to mention our current spectacular lack of success on the sexual front.

He has put a record on and has the headphones around his neck.

SOPHIE Not her. Me. But then, you.

He is about to put the headphones over his ears.

GEMMA Sophie's having a baby Dave, and I'm taking it.

He stares at them, the headphones poised to go over his ears.

GEMMA She's giving it to us.

DAVE slowly, carefully, takes the record off and puts it and the headphones away during the following.

GEMMA I know it's crazy, but it's...wonderful!

SOPHIE You two are going to be a great mum and dad.

GEMMA Scary but tr -

DAVE No. No way. 
SOPHIE She gave her word David.

DAVE I didn't give my word, you little -

GEMMA I want this baby Dave.

DAVE Not going to happen Gemma.

GEMMA A baby, Dave. Our baby.

DAVE We HAD our baby Gemma, and he DIED!

GEMMA I KNOW!

DAVE He didn't even get to have his first birthday!

GEMMA Dave, I know.

DAVE You don't get to replace Tommy just like that! It's not that easy.

SOPHIE No-one's trying to replace Tommy, David.

DAVE It'll get better. Just give me some time, and, and -

GEMMA Here's the way!

DAVE We've just got our lives back together.

GEMMA I haven't got my life back. I still hear him!

DAVE's moving around, upset.

GEMMA Nothing bad's going to happen -

DAVE You don't KNOW that!

GEMMA Dave -

DAVE NO! You do this Gemma and, fine! I pick up that box and I'm out the door. I MEAN IT! Me or it.

GEMMA Dave -

DAVE ME OR IT GEMMA! 
SOPHIE David, look out for the pool!

DAVE I don't give flying fuck about the pool!

He sticks his foot in the pool, splashing beer about.

GEMMA No, you don't give a fuck about anything but yourself!

DAVE

$$
\begin{aligned}
& \text { I was willing to get } \\
& \text { rid of all my stuff } \\
& \text { for you, everything } \\
& \text { that's important to } \\
& \text { me and to you it's } \\
& \text { just a big joke, a } \\
& \text { complete disregard } \\
& \text { for my feelings, } \\
& \text { no, no, it's - }
\end{aligned}
$$

GEMMA All you care about is being a try-hard, wanna-be rock star instead of stepping up to the

\begin{tabular}{|c|c|c|c|}
\hline DAVE & $\begin{array}{l}\text { - a REAL laugh! GEMMA } \\
\text { I've spent this } \\
\text { entire evening } \\
\text { trying to give you } \\
\text { a good time, trying } \\
\text { to recapture what }\end{array}$ & $\begin{array}{l}\text { - ridiculous! SOPHIE } \\
\text { All I want is } \\
\text { a grown-up } \\
\text { relationship } \\
\text { with an adult } \\
\quad \text { instead of a }\end{array}$ & $\begin{array}{l}\text { - enough! Look! } \\
\text { It's late, we're } \\
\text { tired, let's not } \\
\text { say something } \\
\text { we might regret } \\
\text { later or }\end{array}$ \\
\hline & & child who & \\
\hline ow, you & $\begin{array}{l}\text { babies came } \\
\text { along and you } \\
\text { got all sad and } \\
\quad \text { serious. Oh! Except }\end{array}$ & $\begin{array}{l}\text { insists on } \\
\text { hanging onto } \\
\text { adolescent } \\
\quad \text { fantasies about }\end{array}$ & $\begin{array}{l}\text { know? It's just } \\
\text { not worth it, not } \\
\text { with, you know, }\end{array}$ \\
\hline & $\begin{array}{l}\text { this for tonight, of } \\
\text { when, when... }\end{array}$ & & \\
\hline DPHIE & - STUPID! & & \\
\hline EN & & 8 & \\
\hline
\end{tabular}
responsibilities of parenthood and life in the real world yes, yes, it's -

DAVE/GEMMA - ALL ABOUT YOU!

A moment staring at each other.

SOPHIE Listen, you guys, that's -

DAVE/GEMMA About me! That's - 
DAVE I'll show you 'stupid, pathetic, rock star behavior'...

Still with one foot in the pool, he grabs the p.c. monitor off the desk. Papers, books, fly everywhere.

DAVE You want it gone? It's gone!

GEMMA Dave?

DAVE Special request from Sophie!

The T.V. in the Swimming Pool!

SOPHIE Your book -

GEMMA DAVE! IT'S -

DAVE Yarrrrrr!

He throws it into the air above the pool.

GEMMA - STILL PLUGGED IN!

There is a huge electrical flash of light and sound as the p.c. hits the beer.

The entire scene blacks out. And it's the...

\section{INTERVAL}

Music: The Rolling Stones - Jumpin' Jack Flash. 


\section{ACT TWO}

Rolling Stones music plays, but strangely distorted. The lighting of the scene has taken on an ethereal quality too. DAVE stands there, posed just as he was at the end of the first half. However, there are subtle differences. The p.c. monitor and paddling pool are no longer at his feet. And he's alone.

He seems disoriented, as if suddenly coming-to from a deep dream.

He looks about.

DAVE (quietly): Hello?

He listens. Nothing.

DAVE (louder): Hello?

No reply. He starts to move, to look around.

DAVE Gemma? What's going - ooww, shit!

He staggers, his leg giving way beneath him.

He sits and massages it, and as he does, we see memories start to form in his mind. He stares at his leg and foot, then at where the paddling pool, and the p.c. monitor were. Then back at his foot. He takes off that shoe and examines it. The shoe is blackened, melted. He looks back at the spot where the pool was.

His eyes widen as it all comes flooding back.

DAVE Shit. Could've killed myself...

He looks around, becoming a little frightened, noticing for the first time the strange feel and look of the place.

DAVE

What's going...on....Hello?...Gemma?....Sophie?

Listens.

Nothing. 
DAVE (calls) Hey. Not funny...

Listens. Still nothing.

DAVE Stuff this.

He limps over to a table lamp and flicks it on. The scene lights up to almost normal. Outside it's day, late afternoon. He sits on the sofa, rubbing his leg.

Moments later, SOPHIE waddles on, straight past him and into the kitchen area. She looks different, larger around the midriff.

DAVE Oh, hey Soph.

She picks up some mail lying on the kitchen bench. Flicks through the letters, stopping, staring at one in particular. She glances off, then back to the letter. She opens it, reads it, then angrily tears the letter in half.

DAVE Bad news?

SOPHIE looks about, then moves over to the desk, looking through the papers there. DAVE has hobbled over to the kitchen and looks in a drawer. SOPHIE looks in the desk drawer.

DAVE (calls) Where's the 'Deep Heat'? Gem?

He continues to look in the kitchen. SOPHIE has taken some papers out of the desk drawer. She reads them and is clearly shocked and upset.

DAVE (calls) Gem? How about the 'Panadol'?

He continues to look. SOPHIE puts the papers back in the drawer. She takes a big breath and puts on a brave front.

SOPHIE(calling off) I'm making tea! Want one?

DAVE No thanks.

He continues to search through the kitchen drawers.

SOPHIE Hello? Can you hear me?

GEMMA (off) What?

DAVE 'Ponstan.' That sounds like the business. 
SOPHIE Tea! Want one?

GEMMA l'd rather have a wine.

GEMMA enters. She also looks a little different from the last time we saw her. Different hair style, different style of dress. DAVE glances up.

DAVE Hey.

She also goes straight past DAVE, who's busy popping a couple of pills.

SOPHIE We can't have wine because we are kinda pregnant, remember?

GEMMA WE are pregnant?

SOPHIE Mmmm. We like tea, we do.

GEMMA I like wine.

SOPHIE Not long now. Pop some toast on, will you? Ta.

DAVE l'll get you a wine, give me a mo...

DAVE rubs his leg. GEMMA puts toast in the toaster. Looks into the distance. DAVE's testing his leg.

SOPHIE Sleep O.K.?

GEMMA Yeah, thanks to my little blue friends.

She takes a pill container out of her pocket, shakes it. Leaves it on the counter by the phone.

SOPHIE So. What's up?

GEMMA Mmm?

DAVE's hobbling about.

DAVE Ow, shit...

GEMMA I accidentally opened one of his boxes...

DAVE What? A 'Tommy' box? (hobble, hobble) 


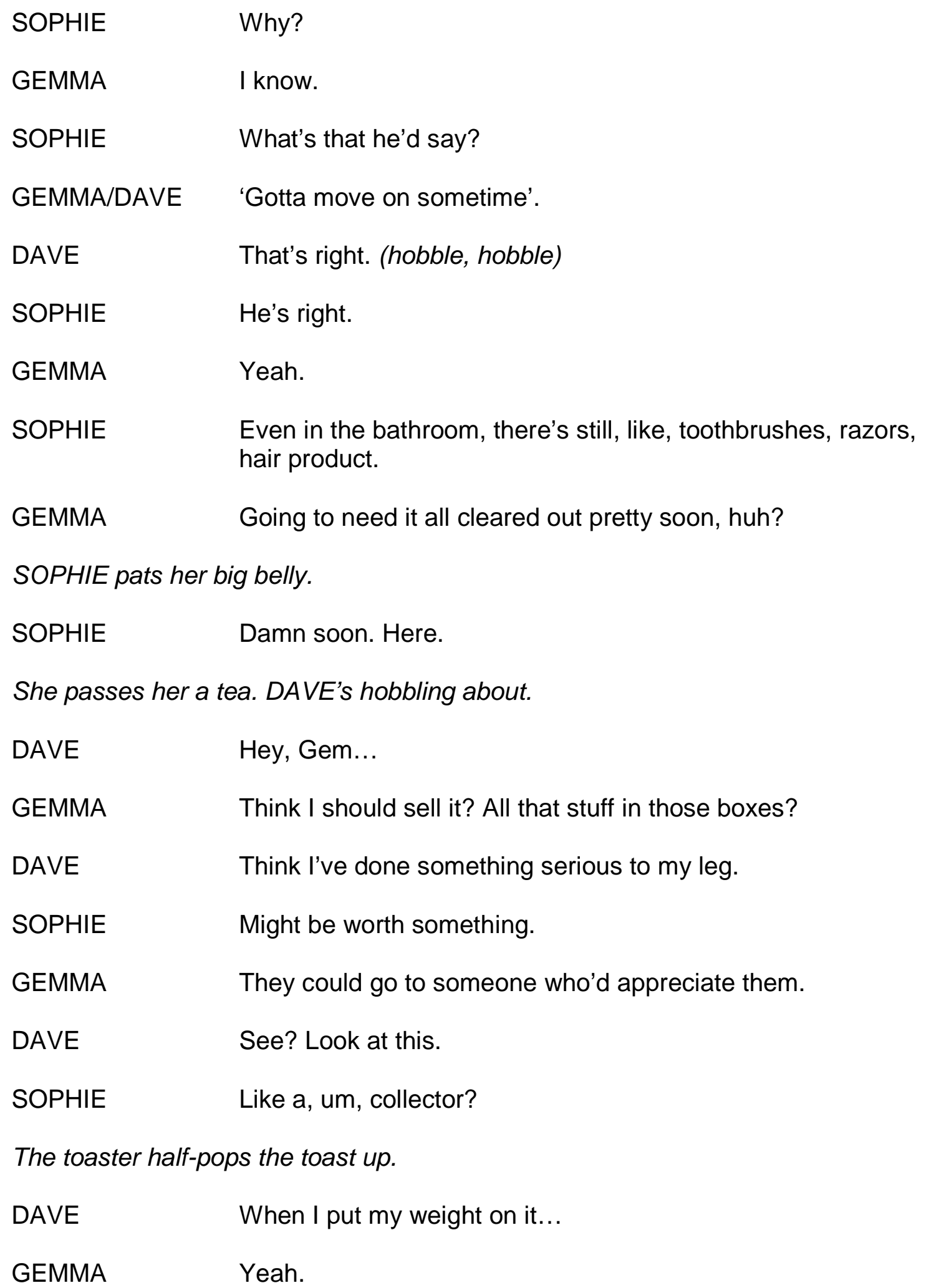


She gets up, and goes to the toaster.

GEMMA Might keep a couple.....

SOPHIE Gemma.

DAVE It kinda spasms or something.

GEMMA Just a couple of his favorites?

DAVE That's not good eh?

He sits, rubs leg.

SOPHIE Why? You can't play them.

DAVE Hey, listen. I'm in pain here.

SOPHIE Not since we got rid of his record player.

DAVE Guys? I'm - What!

He's up and over to where the turntable used to be. It's gone.

GEMMA Yeah, you're right. This bloody toaster...

DAVE The Thorens TD $125 \mathrm{Mk}$ II! Where the hell is my turntable!

SOPHIE No trouble giving it away, then.

GEMMA I was amazed anybody wanted it.

DAVE WHAT! You GAVE IT AWAY?

GEMMA One person's junk is another person's treasure.

DAVE What the HELL do you think you are doing? Where the HELL is my turntable! You DO NOT touch my stuff! You are going right back to whoever you gave it to and get it THE HELL back! Right NOW!

SOPHIE Oh!

GEMMA What?

SOPHIE Kick. 
DAVE

Right NOW Gemma!

GEMMA

Feel O.K?

SOPHIE

Kinda. Pretty scary.

DAVE

Is anybody LISTENING to me!

GEMMA

You should sit. Bring you some toast.

DAVE

I'm BLOODY upset!

GEMMA

If I can get it out.

GEMMA goes to take a knife to the toaster. Stops. Makes a face and tuts to herself. She unplugs the toaster and gets the toast out. During this, they continue.

DAVE Hello? Christ, it's like l'm not even here!

SOPHIE It's normal right? DAVE I just don't matter do I? What's important to me

GEMMA Very normal. means stuff-all to you

SOPHIE Wish Dave was here. give a -

DAVE - what?

GEMMA I like to think that he's here, you know, in spirit.

DAVE Hang on...what?

SOPHIE Here.

GEMMA's getting weepy. SOPHIE passes her a box of tissues.

GEMMA Sorry. And l'm not the one about to have a baby.

SOPHIE No, that would be me. And Gem...

GEMMA Hmmm?

GEMMA blows her nose.

SOPHIE I'm kinda freaking out about it. 
GEMMA

DAVE

SOPHIE

DAVE

GEMMA

DAVE

SOPHIE

DAVE

GEMMA

SOPHIE/DAVE

GEMMA
Right, right. I'm being selfish, sorry.

I don't get this.

Hey, you've had, you know, two major shitty things happen to you. First Tommy, then Dave...

You're saying I'm -

Yeah.

- I'm not here? I'm -

You O.K?

Dead?

Mmmmm.

You sure?

Absolutely. Cheers!

They clink mugs. Drink, smile. Eat toast. DAVE stands there, shocked.

DAVE

GEMMA

SOPHIE

GEMMA

SOPHIE

GEMMA

SOPHIE

GEMMA ....bugger....me...

One thing though.

DAVE $\quad$...so you...

What?

I really, really, don't like herbal teas.

Really?

Yeah, sorry. They actually make me feel sick. Just don't like them.

Actually...yeah, I figured.

You knew?
He does 'the fingers' to the women, several times.

DAVE Can't see me...

He thinks for a moment, then sings as loudly as he can:

DAVE You can't always get what you want! YOU CAN'T ALWAYS GET WHAT YOU WANT! BUT IF YOU TRY... 
SOPHIE I know you're trying to be all supportive, and that. And as much as I really appreciate it, you don't have to make yourself sick.

GEMMA

SOPHIE

GEMMA

SOPHIE

GEMMA

recoils.

SOPHIE

can't

GEMMA

SOPHIE

GEMMA

SOPHIE slightly

GEMMA considers. it all.

DAVE

GEMMA

SOPHIE

DAVE
Why didn't you say?

Huh, why didn't you?

I....

I found it kinda funny, and, my hormones are all over the place. What's your excuse?

I'm just an idiot, I suppose.

You said it, not me.

Right.

Make a coffee, go on.

Better still, have a wine.

You sure?

Go crazy.

Look, if I'm dead, why am I here? Why aren't I somewhere...nicer? Or...nastier? Why am I stuck in my living room, talking to myself?

No, l'm being weak.

Oh, whatever.

Or...is this, like, some sort of limbo, in-between state...?
No reaction from them

DAVE Can't hear me...

He turns and walks straight into a wall, hitting it hard.

DAVE Ow, fuck! O.K. can't walk through walls.

He gestures at a teacup, it doesn't move.

DAVE Hmmm...

He goes to the French doors, suddenly

DAVE Woooo, go out there...

He goes to the hallway, recoils.

DAVE ...or there.

He stands there,

panicked, trying to

make sense of 
SOPHIE Suffer then.

DAVE

Right. I have to suffer. Why, for what.....?

GEMMA O.K.

DAVE $\quad$ For killing myself!

GEMMA You're right.

DAVE I am? I am!

GEMMA It's dumb.

SOPHIE Uh huh.

DAVE It is. It was an accident!

GEMMA I could do with a drink.

DAVE So could I.

SOPHIE Then have one. Jeeze.

She turns to waddle away to the living area.

GEMMA/DAVE O.K.

GEMMA gets a bottle out of the cupboard, ducking down out of sight. DAVE gets two glasses off a shelf and puts them on the counter. A routine they've done many times before. He then slumps on a bar stool. GEMMA emerges, sees the two glasses sitting there. Slight frown, glances at SOPHIE moving off.

GEMMA Thinking of keeping me company?

SOPHIE Pretend l'm drinking with you.

GEMMA smiles, nodding, and pours wine into both glasses. She takes one with her through to the living room area to join SOPHIE. Behind her back, DAVE takes the other glass.

GEMMA/DAVE Cheers.

SOPHIE Back at cha.

GEMMA Mmmm. Oh. Steve called earlier too. Said he's been trying 
to get hold of you.

SOPHIE

GEMMA

DAVE

GEMMA

SOPHIE

GEMMA

SOPHIE

GEMMA

SOPHIE

GEMMA

SOPHIE

GEMMA

DAVE

SOPHIE

GEMMA

SOPHIE

GEMMA

SOPHIE

DAVE

GEMMA

SOPHIE

GEMMA
That right.

Yeah.

Why's he sniffing around?

Watch out for that one, young Sophie.

Listen. I accidentally opened some of your mail.

...uh huh...

You gave your word Gemma.

Look, Soph -

I trusted you.

I haven't done anything.

So why's an adoption agency writing to you?

I'm, just, you know, checking out our options.

The baby. It's because I said "no"..

Gemma.

Listen -

Can't change your mind now!

It's O.K. Just an enquiry.

You gave your word.

Cosmic revenge for saying no to a new life.

Take it easy, nothing's going to happen.

Your word.

I'm sorry. I got scared, but now it's fine. 
Pause. They stare at each other.

SOPHIE Sure?

GEMMA nods. She's picked up a pad with lists and lists on it.

SOPHIE Wouldn't lie to me?

GEMMA Right, names!

SOPHIE Gem.

GEMMA Come on, we're narrowing it down.

SOPHIE To what? Only six pages?

GEMMA Five. Now focus...

DAVE Look, I'm sorry, O.K? I felt...trapped. I felt it was forced upon me and we were just about right again and moving on and the book was shaping up and I thought I could get the band back together and why the hell am I talking to the light fixture in the ceiling?

He finishes off his wine and puts it on the counter. Meanwhile the women have been going down the lists. GEMMA flops back on the sofa. Drinks wine.

GEMMA Put them all in a hat, pull one out?

SOPHIE Um. What was Dave's middle name?

GEMMA Oh, ah...

DAVE $\quad$ Frederick.

GEMMA $\quad$...Frederick.

GEMMA/SOPHIE Noooo!

They laugh.

DAVE Why not?

GEMMA What's the biological father's middle name?

SOPHIE $\quad$...don't know. 
GEMMA His first name?

SOPHIE Gemma.

GEMMA Just asking.

SOPHIE Leave it. Please.

GEMMA finishes off her wine, gets up and crosses to the counter where the bottle and other, now empty, wine glass sits. She puts her glass down.

GEMMA Could've sworn...look Sophie, don't get me wrong, l'm not judging you. Far from it. I completely understand how...

As she talks to SOPHIE she turns away from the counter. Still feeling sorry for himself, DAVE refills both their glasses, sips his and puts it back on the counter next to hers.

...us girls can be left literally holding the baby. It happens, I know. But this is dumb. I'm on your side....look...

Without really thinking about it she turns, picks up her re-filled wine glass, sips and continues.

... I understand drunken one night stands and...

Momentarily, she frowns. Something's amiss. Then she continues.

...that gig? Remember? That I 'accidentally' attended?

SOPHIE The 'groupie' gig.

GEMMA Loved that didn't he?

SOPHIE Yeah.

Pause. GEMMA looks off, remembering.

SOPHIE Gem? That gig?

GEMMA He...was amazing. Normally bass players are, you know, the quiet ones. Not Dave. He owned the stage that night. A crappy little bar, in a grotty student pub, with about a dozen people in it. Completely off their faces. Me included. 
SOPHIE

GEMMA

SOPHIE

GEMMA

SOPHIE

GEMMA

DAVE

SOPHIE

GEMMA

DAVE/SOPHIE

GEMMA

SOPHIE

DAVE

GEMMA

SOPHIE

GEMMA

DAVE

GEMMA

SOPHIE

GEMMA
Ooooo Gemma

I know. And god, they were loud! And the bass, you know, those deep notes, those...good vibrations....well...

Uh, huh.

Yeah, he was very attractive that night. They all were. Even that idiot Steve.

Right.

Who was actually quite good looking.

Whatever.

This is going somewhere sexual right?

Oh, yeah. Christ, this wine, you were right, wooo. Brilliant. Anyway, where was I?

Going somewhere sexual.

Oh! Yes! So. That night, after the gig. Dave and me... y'know.

Uh huh.

Right. I remember.

And so, I went to the next gig, the next night, and the one after...

And each time, afterwards, you got with Dave?

Well, that's the thing. They were all very attractive, even Steve.

What!

And me and Dave, we weren't a couple or anything.

So...

Yep. 
DAVE

With Steve!

SOPHIE

Shit, that's very, um, groupie of you, Gemma.

Ever tell Dave?

DAVE

NO!

GEMMA

No point.

DAVE

Oh my god Gemma! You, you....slut!

GEMMA

We were young. Stuff happens.

SOPHIE

Right. Look at me.

GEMMA

Then Dave and I got married, got a mortgage and one year and 9 months later Tommy came along. It was all good.

SOPHIE Yeah

GEMMA Thing is, Dave's birthday party last year - you were there, right?

SOPHIE Yep.

GEMMA Well, there was a fair amount of alcohol involved, don't remember too much, but, um, looked like history was going to repeat itself...

SOPHIE

Did it?

Pause.

DAVE

Gem?

GEMMA

No, thank Christ. Couldn't have lived with myself!

SOPHIE

Huh.

GEMMA Think he must've gotten a better offer.

GEMMA stares off. DAVE just doesn't know what to do with himself.

DAVE

This is, this is...HELL. 
SOPHIE What about...Steve?

GEMMA/DAVE Huh?

SOPHIE struggles to her feet.

SOPHIE Nothing.

GEMMA swigs from her glass.

GEMMA Hey, look. Listen. My point being, l've been there, O.K?

SOPHIE Right.

GEMMA So. Our baby's dad?

SOPHIE Don't think that's -

GEMMA He's obviously not in the picture Soph. It's down to you and me.

SOPHIE Gemma, I can't.

GEMMA No one's going to judge you.

SOPHIE Gem -

The wallphone goes. SOPHIE, being on her feet, goes and answers it.

GEMMA Saved by the bell.

SOPHIE(on phone) Hello? Oh. Hi.....no......I said no! And do not call me here again...I don't care! NO! You keep away from....No! Leave me ALONE!

She slams the phone down. Fiddles with the pill container. Sees GEMMA looking at her, concerned.

SOPHIE Phone surveys. Hate them.

GEMMA What's going on here Sophie?

SOPHIE I don't know what the hell l'm doing having this baby.

GEMMA Hold on a minute - 
SOPHIE I'm shit scared and when it's over l'm right back where I started.

GEMMA Sophie -

SOPHIE I can't go home. They hate me.

GEMMA We'll work it out. I promise.

The women look at each other.

SOPHIE You taking my baby means...I get to see it.

GEMMA Soph...I -

SOPHIE Gotta go pee.

GEMMA Hey.

SOPHIE It's O.K. But, um, take it easy with that wine, I need you.

You're, you know, all I got.

Taking the pill container, she waddles off. GEMMA watches her go, sipping her wine, and then something else catches her eye. She gets up and goes to the shelf and picks it up. The Baby Monitor. DAVE looks on feeling a mixture of love and betrayal.

GEMMA (to self) Oh god. What am I doing? Dave...

DAVE What? Hello?

GEMMA You beautiful fuck-up. Why'd you leave me?

DAVE I...weirdly, Gemma, I haven't.

GEMMA Why won't you hold my fucking hand? Is that too much to ask for? Just hold my fucking hand, help me get through this.

DAVE I...I'm so sorry Gem.......

GEMMA I can't do this. I can't. I'll screw it up again.

GEMMA goes to the desk and brings out the papers. Looks at them, as does DAVE. 
DAVE 'Consent to Adoption'? Bit more than just an enquiry Gem.

SOPHIE has appeared, unseen, in the doorway.

GEMMA I gotta do this. S'for the best.

Weeping, GEMMA signs the papers and stands there shaking.

SOPHIE turns quickly and exits.

DAVE reaches out to hold GEMMA's hand. Hesitates. Then takes her hand.

A moment, then GEMMA shivers, stands strong and looks around. DAVE backs off. GEMMA frowns.

GEMMA You bitch.

She looks down at the forms, talking to herself in an angry whisper.

GEMMA Don't you dare let them down. Don't you dare.

She tears the forms in half. Catches her breath. Calls off.

GEMMA Sophie! Come and distract me! What's taking you so long?

She listens for a reply.

GEMMA I'm talking to dead people in here!

She listens for a reply.

GEMMA Sophie?

GEMMA goes to stand in the doorway looking off.

Hey, you were right about being careful with the wine Jesus, Sophie!

GEMMA dashes off. DAVE close behind her. He recoils from what he sees off.

DAVE Holy shit! Where'd all that blood come from?! My god! My god!...I'll...l'll call 111 !

He runs to the wall phone. Stops, staring at it. 
Can I actually call 111 ! (calls) I don't know if I can call

111! Gemma? I don't know what I can do! GEMMA?

Shit!

He takes a big breath and grabs the phone. O.K. So far, so good. Gaining confidence, he stabs 111 and puts the phone to his ear.

O.K.! (calls) I'm doing it Gemma! Hang on, Sophie! (to phone) Hello? Ambulance. Hello? Hello? Yes, I can hear you. Can you hear - ? Hello? Hello? Yes, I'm here. (calls) Gemma! They can't hear me! (to phone) Nooooo! Don't hang up! Hello? Hello? SHIT!

He throws the phone across the room, and runs towards the doorway just as GEMMA assists SOPHIE through and onto the sofa. There are bloodied towels around her left wrist. They both look pale and shocked.

DAVE What the hell Sophie?

SOPHIE Sorry, sorry, l'm so sorry...

GEMMA Sshhh, sshhh, just sit. Sit. l'm just going to call an amb -

SOPHIE l'm O.K.! Dumb, dumb, thing to do...

GEMMA Where the hell's the phone?

DAVE Oh, shit, what'd I do with it?

He looks around for it.

SOPHIE Christ, it hurt.

GEMMA Keep the pressure on that.

SOPHIE How the hell you're meant to do both wrists?

GEMMA What on earth Sophie?

SOPHIE Good question. Found one of Dave's old razors.

GEMMA Why?

SOPHIE You don't want me or this baby. 
GEMMA What?

DAVE pops up from somewhere waving the phone.

DAVE

SOPHIE

GEMMA

DAVE

SOPHIE

GEMMA

SOPHIE

GEMMA

SOPHIE

GEMMA

SOPHIE

GEMMA

SOPHIE

GEMMA

SOPHIE

GEMMA

SOPHIE

GEMMA

DAVE looks on.

\section{Found it!}

I heard you just now.

Darling girl. Drunken talk to a dead husband doesn't count.

I'll just put it back, shall I...?

I found the forms Gemma.

What?

The Consent to Adoption forms! The forms you've filled in!

Listen -

You lied to me Gem! You're giving the baby away.

No -

I saw the forms!

I tore them up.

I wanted you to have this baby.

Sophie, I tore them up!

I'm scared Gemma.

So am I. I lost my baby. How d'you think it feels facing that possibility again?

Gem -

Dave couldn't do it! As much as I wish he was here, he'd...I need you, Sophie. We help each other, O.K?

GEMMA

Look, this cut's not so bad. 
SOPHIE cries.

GEMMA

SOPHIE

GEMMA

SOPHIE

GEMMA

SOPHIE

GEMMA

SOPHIE

GEMMA
Hey. And I want this baby.

Don't think so, Gemma.

Couple of stitches -

You wanted to know the father's name.

Oh, Sophie, it's not - [important]

My baby's father's name is...Stephen.

O.K. Fine.

Though a lot of people call him...Steve.

Uh, huh, like Dave's mate...

SOPHIE looks at her, tears streaming down her face. GEMMA goes white.

DAVE What? NO!

GEMMA Oh god. Dave's party -

SOPHIE nods. GEMMA gets up, turning away, shocked.

SOPHIE sits there sobbing. As she cries a pill container falls from her hand.

DAVE Oh, jeesus. Oh jees. Those are Gemma's tablets!

DAVE grabs the pill container, shakes it. It's empty.

DAVE Oh shit. This is bad, this is...

DAVE sees he needs to do something. But what?

He goes to GEMMA who is now standing there shaking, wide-eyed with shock.

DAVE Sorry Gem, but you gotta keep it together.

He slaps her quite hard across the cheek.

GEMMA (shocked) Jesus!

DAVE O.K., now you're back with us. 
Blinking rapidly, GEMMA looks around then focuses on SOPHIE, and goes to her. SOPHIE I should've killed it! You don't want it!

GEMMA No more babies are dying around here. That's what I want. That and a slow and painful death for a certain drummer.

SOPHIE flops and we see that the towel is even more bloody than before.

DAVE Oh, god Gemma, that's a lot of blood.

GEMMA Come on darling girl. No time for sleeping! Gotta try and find the phone...

She looks up and sees that it is back on the wall cradle.

GEMMA What? O.K. found it, Soph. Sophie?

SOPHIE $\quad$...so tired Gemma, not feeling so good...

DAVE grabs the phone and brings it to them, but they are focused on each other.

GEMMA Sophie! Sophie! Focus! I'm just going to make a call where the fuck is the phone!

She has turned to see that the phone is no longer on the wall cradle.

DAVE Here! Here it is!

He waves it, unseen, in the air behind them.

GEMMA Forget that. We're gonna take a ride Sophie, off to the car now.

SOPHIE $\quad$....love this....duvet...

GEMMA Off in the car to the hos - Oh shit, where's my bag, where's my car keys!

SOPHIE passes out.

GEMMA Soph! Sophie...

$D A V E$ dashes around looking. Suddenly gets an idea. Stabs numbers on the phone handset. A cellphone starts ringing. 
GEMMA That's my cell.....which is in my...

Gemma looks for, and finds her bag half under a chair. Gropes around in it.

GEMMA My bag! And....my phone, and... my car keys! Soph. We're outta here! Thank you, caller, your timing is heavenl-

She checks the caller i.d. Obviously it says 'home'. She looks about, bewildered.

SOPHIE Gem...Gemma...

GEMMA Hey, hey, it's not so bad.

DAVE Gem, it's real bad.

SOPHIE Mmmm, sorry...0000...

DAVE Go! Go! Get her to the hospital!

GEMMA O.K.! Up we go, help me here, Sophie, come on darling girl, give me a bit of a hand here, that's it, off we go...

GEMMA struggles to get the fainting SOPHIE up off the sofa. DAVE takes her other arm, and they get her up and to the doorway. He recoils away from 'outside' as before, letting go of SOPHIE's arm.

Struggling, GEMMA takes her off up the path and out the gate.

DAVE watches them go from the doorway. He waves the phone hand set.

DAVE I can't call! I can't ...do anything! I'm so sorry. I'm useless! I'm...dead! I'm useless to you! Just like...like when I was alive...oh, god, Gemma. I'm...

He comes back inside and stands there, the phone in his hand. ...useless.

Suddenly, the phone in his hand starts to ring. He jolts to.

S-shit!...Hello?...Is this... Steve?...Steve! Don't give me that 'Is anyone there?" crap. You fuck! I'm here, arsehole! You can't hear me, but hear this!

He violently bangs the phone on the counter. Yells into it. 
Yeah! You want some more of that, you bastard!

He bangs the phone some more. Yells into it.

How's THAT!

Bangs. Yells.

\section{I'LL FUCKIN' HAUNT YOU, YOU FUCKER!}

He bangs the phone. It breaks. He keeps banging. It smashes to pieces. He yells into whatever's left.

She's just a kid you arsehole! She doesn't know it's just a game we play, just the pathetic rock fantasies of losers who kid themselves they're still kids. Kidding themselves, kidding everyone...

He throws the smashed phone across the room.

...I'm supposed to be your mate and you knew that I knew Gemma was the one and my life, my whole life my life my ...oh my god...

He breaks down, sinking to the floor. Eventually:

...isn't...isn't... death supposed to...sort shit out? This is... as bad as... life. All this... is killing me. l've had enough. What about a bit of...tunnel of light?

He looks about, expecting...something. Nothing

Come on. Or...at least...that floating-'round-the-ceilinglooking-down stuff? That's nothing, that's common. That'll do. Float me on up there, sounds good.

He shuts his eyes, waits to float. Nothing happens. He opens his eyes.

Oh, come on! This is cruel. Heaven. Hell. Whatever. Just. Do. It. I can't DO anything here!

He stands there, ready. Nothing.

Please. It's too sad. I'm done here. Come on, send me wherever l'm going...Please. 
Nothing. Then...

The lights flicker, dim, then flicker some more. Slightly surreal feel.

DAVE Alright! There we go. Freaky stadium lighting stuff. Thank you...

The light above the kitchen table flickers and goes out with a pop.

DAVE Or...a blown light bulb. O.K., no problem, no problem. We'll say that was just the warm-up. The opening act.

Main event now. Headliners. Let's try for the tunnel to the sky -

SOPHIE What makes you think you deserve that?

Unseen by all, SOPHIE has appeared in the kitchen area. She has a bandage around her left wrist and is obviously no longer heavily pregnant. In fact, she looks a little older.

DAVE

S-Sophie?

SOPHIE

You took off, left us to cope.

DAVE

I...died!

SOPHIE

Whatever. We needed you.

DAVE

Hold on. You can see me? Hear me?

SOPHIE

'Course.

DAVE

But...you couldn't, just before -

SOPHIE

Yeah, but I had a feeling you were, like, still hanging around.

DAVE I didn't want to!

SOPHIE You couldn't help and you couldn't just let us get on with it?

DAVE What's happening here?

SOPHIE I don't know. It's kinda fuzzy. I remember travelling in the car on the way to the hospital. Then I'm here, listening to 
you talking about light bulbs.

DAVE You can definitely see me?

SOPHIE What do you think?

DAVE I think...you should look at yourself.

SOPHIE What?

DAVE $\quad$ Check out your...

He gestures at her midriff. Frowning, SOPHIE reaches for her large stomach, only to find that it isn't there.

SOPHIE My bump! What's happened?

DAVE To use one of your favourite phrases: good question.

She stares at him, starting to work it out.

SOPHIE Am I...?

DAVE I think you just might be.

SOPHIE I'm...

DAVE Don't think you made it to the hospital. Sorry.

SOPHIE $\quad$...like you? I'm -

DAVE If by 'like me' you mean -

SOPHIE/DAVE - dead.

DAVE Yeah.

SOPHIE Dead!

DAVE It's tough at first, but actually, it's not so bad.

SOPHIE Not so bad? It doesn't get any 'badder' than dead, Dave.

It's, like, the ultimate 'bad'!

DAVE And I think you're stuck here in a kind of limbo as punishment for killing yourself. 
SOPHIE Huh?

DAVE And Time seems to leap about a bit.

SOPHIE Time?

DAVE And no one can see, or hear you. Yeah, that's about it.

SOPHIE Oh my god, I'm -

DAVE Er...condolences.

SOPHIE I'm d-dead.

Just then, one of the French Doors opens and GEMMA enters. Again, she looks a little different. She hooks the door open. Dumps her bag and some forms on the kitchen counter.

SOPHIE Gemma! Can you see me?

DAVE She can't.

He's right. She can't.

SOPHIE GEMMA!

DAVE Or hear you.

SOPHIE This sucks!

GEMMA has now opened and hooked back both doors, and goes back out, only to return pushing a baby stroller through and into the living room area.

SOPHIE Oh.

GEMMA talks to the unseen baby in the stroller.

GEMMA Okayyyy then. Okayyyy then, here we are, here we go, in the door, in through the door, back home, safe and sound. Yes we are. Yes we are then.

GEMMA unloads a box from under the stroller, putting it on top of the forms on the kitchen counter, as she continues to talk to the baby.

GEMMA I think we're tired, yes we are, we are tired, aren't we, yes, 
oh yes, I think so.

SOPHIE Oh, my god, is that..?

GEMMA Oh my big boy! My great big boy with a great big yawn! Mummy knows, mummy knows it's his bed time. Come on then...

GEMMA takes the stroller off. SOPHIE and DAVE stand there open-mouthed.

DAVE So Gemma got to have a baby.

SOPHIE Yeah.

DAVE You didn't make it, but...

He looks at her. She's flushed, emotional.

DAVE You O.K. with that?

SOPHIE $\quad$...she TOOK him. I was so scared...

GEMMA re-enters with the stroller, carefully, quietly, closing the door behind her. She parks the stroller, and takes the Baby Monitor off the shelf. She puts it by the sofa and then walks straight past them, goes to the kitchen, gets a glass and a bottle of wine.

GEMMA (to self) Grown-up time.

She pours herself a glass, and plonks down on the sofa, exhausted. Sips. Talks quietly to the monitor.

GEMMA Sleep, little one. Sleeeeeeeep now. Please. You're killing me. Please sleep. Please.

She starts to cry. Stops herself. Sits up straight and strong. Then cries again.

DAVE (softly) Oh, Gemma...

SOPHIE(whisper) Tissues...

DAVE, looking very concerned, carefully, slowly edges a box of tissues towards her. GEMMA doesn't notice its arrival, but takes one and wipes her eyes.

DAVE (whisper) That's it... 
GEMMA weeps a little more, but blows her nose, breathes deeply, and starts to get it together.

DAVE (whisper) …that's my girl...

SOPHIE(whisper) Dave...

DAVE (whisper) What?

SOPHIE(whisper) Why are we, um, whispering..?

DAVE(whisper) 'Cos...she's upset...

SOPHIE But she can't hear us.

DAVE(whisper) Ssshhh! Come on, let's give her some space.

He moves away.

SOPHIE And...

SOPHIE follows him.

SOPHIE $\quad$...she can't see us.

DAVE That's not the point. Show her some respect. She's had a hell of a time. First Tommy. Then me. Then you. Christ, she's almost got a season's pass at the cemetery. How much can one person handle? No, we've got to look after...

He tip-toes over to behind GEMMA and, unseen by her, refills her wine glass. Tip toes away.

...her. Be there for her.

SOPHIE But, um, we're not there.

DAVE I get it now. She needs me, and I'm not going to stuff it up like last time.

SOPHIE How?

DAVE I can... watch over him while she sleeps! See!

He gestures, and indeed, GEMMA has nodded off. 
DAVE

I don't sleep. I think. I'll constantly be on alert. I can... push the alarm button on that monitor. I can... pour wine. Pass tissues. And...I'm low maintenance. I don't need any washing done, or meals cooked. I'll even listen to her, I've got all the time in the world. I CAN DO THIS!

SOPHIE

The perfect husband. Apart from, um, oh yes, being dead.

DAVE

Oh! And I can work on my book.

SOPHIE

Yeah?

DAVE

On the computer. At night. Look, she got a laptop. I can still type. I can email. I can contact publishers. I can do the lot. Oh! Sophie! (a realisation) You know what?

SOPHIE What?

DAVE I'll be a ghost writer.

SOPHIE Oh, groan.

DAVE This is brilliant!

SOPHIE Wow, you are obviously really fired up about this.

DAVE Sophie, l've never felt so alive.

She grins, shakes her head.

SOPHIE $\quad$...bound to be a certain, um, percentage of people using the internet that are dead. Get all sorts on there...

They look at the sleeping Gemma. Glance off to Tommy's room. Look at each other.

DAVE Why, Sophie?

SOPHIE Huh?

DAVE With Steve?

SOPHIE No choice. The bass player was taken. Groupie rules.

DAVE looks at her, frowning. She goes to the box GEMMA put on the kitchen 
bench earlier.

SOPHIE What, um, do you think she named him?

He's still looking, thinking.

SOPHIE Probably not 'Fredrick' eh? Oh, look - "Dave's.”

She indicates the writing on the side of the box. DAVE goes to it. He opens it, reaches in and lifts out his turntable. The Thoren TD125 Mk II. He gasps.

DAVE I thought you...

Something else catches his eye. He carefully puts the turntable down, and reaches into the box. He brings out an EP. It's 'Five By Five'.

DAVE Huh. Look at that.

SOPHIE The magic record.

They stand there. She smiling. Him kind of worried.

SOPHIE Hey, you got to have your spectacular rock star death, you know.

DAVE Is that what I had?

SOPHIE It was pretty full-on.

He looks at the sleeping GEMMA.

DAVE She was going to leave me you know.

SOPHIE Who? Gemma?

DAVE No, my other wife. Yes, Gemma.

SOPHIE Right. Sorry.

DAVE I don't blame her. Imagine living with a guy whose heart's in the sixties, and whose head's in the clouds.

SOPHIE What made you think she was going?

DAVE I found a packed bag. With her passport, money, other stuff. 
SOPHIE When?

DAVE Just after...Tommy.

SOPHIE But, she didn't go?

DAVE She never unpacked it. I kept checking. Thought she'd not need it after a while, but...

SOPHIE Maybe she, um, forgot it was there.

DAVE No, she knew it was there.

He picks up the turntable, takes it to the rest of the stereo, and plugs it in during the following.

DAVE $\quad$ For when she finally gave up. When she'd done all she felt she could, she could just go. Quickly. Bags packed.

SOPHIE Oh.

DAVE So I waited for it to happen.

SOPHIE Did you ever tell her you knew?

DAVE shakes his head.

DAVE Waited for it to go away.

SOPHIE Maybe she wanted you to find the bag. Maybe she was waiting for you to say something about the bag.

DAVE looks at her. Picks up the E.P.

SOPHIE Maybe she was hoping that you would. Say something. Do something.

DAVE What?

SOPHIE looks at him.

SOPHIE Anything.

SOPHIE tidies the now empty box away, revealing the forms underneath. 
GEMMA jerks awake. She checks the Baby Monitor then gets up tiredly and goes off.

DAVE stands there holding the record.

SOPHIE What are these?

SOPHIE picks the forms up, reads.

DAVE Something Gemma brought in.

SOPHIE Oh my god Dave! Adoption papers.

DAVE What?

SOPHIE She's adopting out my baby! She's giving him away!

DAVE Let me see that.

He scans the papers.

SOPHIE She's filled it all out!

DAVE She...hasn't signed it!

SOPHIE She's going to sign it!

DAVE What the hell, I saw her tear these up.

SOPHIE She got new ones!

DAVE Hang on -

SOPHIE Hide the form! We can do that!

DAVE She must be...she's -

SOPHIE Or we could burn it, or, or -

SOPHIE runs to the doorway leading off. Turns back to talk to DAVE.

SOPHIE We take him!

DAVE What?

SOPHIE We...spirit him away! We take him, and we love him, and 
we look after him, and -

DAVE Soph -

SOPHIE WE MUST DO THIS! It's not his fault!

DAVE Leave it Sophie.

SOPHIE HELP ME!

DAVE Nothing we can do.

SOPHIE Get stuffed you fucking ghost.

She exits.

DAVE Sophie....

DAVE stands there, looking, feeling, hopeless. He sees the E.P. in his hand.

At a loss for anything else to do, he goes to the stereo and puts the record on. As soon as the first track starts to play, the lights change.

Behind him, GEMMA enters through the French doors. She looks a little different. She dumps her bag on the floor, half under a chair.

GEMMA It arrived safely then.

DAVE Yeah...w-what did you say?

GEMMA Your precious turntable. The one you spent hours on the net looking for. What is it, a Thornbird 2000?

DAVE A Thordon TD 125, mark t...can, can you see -

GEMMA I stand corrected. You opening the wine?

DAVE Gemma. W-what's going on?

GEMMA Dave, don't. I've had a hell of a day. I really don't need the third degree right now. Sorry if I'm not bowing down in awe of your record-player. I just want a glass of wine.

DAVE Look, listen. I -

GEMMA A glass of wine! Please! 
DAVE ....Right.

GEMMA Thank you.

DAVE goes to the fridge, and gets a bottle out. He then gets glasses out of a cupboard as he tries to work out what's going on.

DAVE You...O.K?

GEMMA

I've been feeling like crap all day. And of course it's today that upstairs want the figures for the last quarter. In Power Point. And my computer crashes halfway in. AND I.T. just don't want to know!

DAVE

Oh. Huh.

He hands her the wine and frowns. This seems familiar...

GEMMA

Ta. We didn't drink that much last night did we? I felt really nauseous this morning.

DAVE

...not sure...

GEMMA

Actually, sorry, no, wine's the last thing I feel like. Pop the kettle on for me will you hon.? Sorry to be such a lazy cow, but l've been on my feet all day.

DAVE No problem.

GEMMA Nice sounds. What's this?

DAVE

'If You Need Me' Track one. Five by Five.

GEMMA

Hmm. How'd it go here? How many pages? How many words?

DAVE Huh? The...book! I'm writing -

GEMMA O.K.! Alright! You've made a start. I thought you'd spend the day plunking away on your bass.

DAVE

Um. No.

GEMMA

Sorry babe. I'm such a bitch. Course the book's gonna happen. And it'll be brilliant. Confess though! Did Steve 
call?

DAVE Steve?

GEMMA Take up valuable writing time with band reminiscing?

DAVE I...remember...this day...something big happened...

GEMMA Amazing he remembers anything, so out of it most of the time. Tosser.

DAVE You used to...like him once.

GEMMA Yeah, well. I must've been out of it too.

DAVE And then you said -

GEMMA/DAVE 'Luckily I sobered up and got my hands on the right guy.'

GEMMA Mind reader. I'm going to have a bath. Know what I'm thinking l'm gonna need after that, big boy?

DAVE $\quad$...someone to dry you.

GEMMA You are psychic.

DAVE Gem. Seriously. Did you?

GEMMA What?

DAVE Get your hands on the right guy?

She smiles at him.

GEMMA And then some.

She gets up and gives him a wee kiss.

GEMMA And then some more. Oooh, feel really yuk...

DAVE $\quad$...and then you walked to the hallway, turned, and said -

GEMMA has done as he described.

GEMMA Hey. You better not have got me pregnant, you stud. 
GEMMA exits, laughing. DAVE stands there, open mouthed. The track on the E.P. finishes. Subtle reset of lighting.

DAVE ....I remember that day! This day. I got the Thordon. Gemma found out she was...This is years ago. What the hell? Aren't I dead anymore?

Suddenly, grabbing his attention, the next track on the E.P. begins. Then, with a lighting change, there is a knocking on the French doors. DAVE spins to see a young-looking SOPHIE standing there, wearing her school uniform. She gives a little wave. He opens the doors.

DAVE Sophie!

SOPHIE Hiya.

DAVE What's...what's up?

SOPHIE The usual. School sucks. Life sucks.

DAVE Oh.

SOPHIE What's this playing?

She comes in and flops onto the sofa.

DAVE 'Empty Heart' Track two. Five by...Um. The Rolling Stones.

SOPHIE Where's Auntie?

DAVE Um.

SOPHIE Not long to go now. Pretty exciting.

DAVE Until what?

SOPHIE You two have got it sussed you know?

DAVE Yeah?

SOPHIE And baby arriving any second. Wish it was me.

DAVE Um. Soph. This is going to sound weird, but, um, what's the date today? 
A hugely pregnant GEMMA enters from the hallway, waddling straight across to the kitchen.

SOPHIE The date?

DAVE $\quad$ Forget it. I can see -

GEMMA Ooh, don't look at me.

DAVE You're...beautiful.

SOPHIE Reckon.

GEMMA I'm a whale. Hi Soph.

DAVE This is amazing. You're -

GEMMA A small planet. I should be orbiting the sun.

SOPHIE Get you anything Auntie?

GEMMA A wine.

SOPHIE No can do. Naughty, naughty.

GEMMA It's not fair. Ooooo...

SOPHIE Tea?

GEMMA Why do ! have to be the pregnant one?

DAVE $\quad$ Feel O.K?

GEMMA No Dave, I feel like crap. Going to lie down again.

SOPHIE I'll bring it through.

GEMMA Thank you Sophie. What would I do without you?

She exits, eye-balling DAVE.

SOPHIE Want one too Uncle David?

DAVE So, this is, when?

SOPHIE Chamomile? 
She holds up a cup. Smiles.

GEMMA (off) Dave! I don't want Sophie walking home at this hour.

DAVE (calling off) Huh?

GEMMA (off) When she wants to go. You need to give her a lift.

SOPHIE 's O.K. I can get -

GEMMA (off) So don't drink.

SOPHIE The bus or something.

GEMMA (off) Dave?

Slight pause.

DAVE (calling off) Sophie's staying here with us for a while.

They look at each other.

DAVE If you want.

SOPHIE Cool. But...?

DAVE Like she said, what would we do without you?

SOPHIE smiles, and then takes a cup of tea off. DAVE talks to himself, trying to get a handle on what's going on.

DAVE O.K., this is later -

GEMMA (off) Dave!

DAVE Gemma's -

GEMMA (off) Make us a pickle sammie?

DAVE - very pregnant.

GEMMA (off) Dave?

DAVE And - 
GEMMA (off) Is the air-con on? I'm boiling.

DAVE - I'm -

GEMMA (off) Dave?

DAVE - - frigging confused.

The music plays on.

GEMMA (off) Turn it down a bit hon.

He stands there.

GEMMA (off) Dave?

DAVE (calls off) 'K.

DAVE moves towards the stereo as the track on the E.P. finishes.

Briefly it's quiet. He looks at the record.

The next track on the E.P. begins. Lights change.

DAVE Track three. '2120 South Michigan Avenue'.

GEMMA (off) Dave!

He turns, not sure where her voice is coming from.

GEMMA (off) Dave! Need a hand here!

It's from the garden.

GEMMA (off) The stroller! The bloody thing's jammed or something. Dave!

He tries to go out the French Doors and is repelled as before. GEMMA enters into the garden area.

GEMMA (off) Dave!

He grabs his headphones, puts them on. Moments later, GEMMA, SOPHIE, bags, and baby in stroller, all struggle on in.

DAVE Sorry, didn't hear you. Had my, um, you know, on. 
GEMMA

As per. The stroller's stuffed.

DAVE suddenly realises that the headphones aren't actually plugged into the stereo and quickly tidies them away.

SOPHIE So what do you reckon?

GEMMA Why not? Dave?

DAVE Mmm?

GEMMA Sophie just said 'what about a half year birthday?' Why wait 'til one years old?

DAVE (bewildered) Huh?

GEMMA Oh, and I've given Sophie the spare key, so you'd better get another one cut.

DAVE O.K.

GEMMA And, yeah, yeah, I know what you're thinking, it's a dumb idea, it's not traditional, Tommy doesn't know any different, but Dave, we haven't had any fun for months, and why not, eh, babe, why not celebrate his first 6 months? Why not celebrate every month, every day? I mean, you know?

SOPHIE Just an idea.

They look to him. Slight pause. He recognises this event.

DAVE I didn't like this last time, too much effort, but...actually, it's...a brilliant idea.

GEMMA Oh Dave, that's great.

SOPHIE Got him a present.

She pulls a package out of her bag.

GEMMA Oh, Sophie, you can't afford -

SOPHIE I wanted to.

GEMMA Darling girl. His Daddy'll open it while I get the bath ready. 
SOPHIE Let me take him through.

GEMMA Come on, it'll take the two of us to keep him, and all the water in the bath. He's such a big boy! Aren't you Tommy! Such a big boy!

They go off with the baby stroller. Seconds later GEMMA pops her head back in.

GEMMA (loaded whisper) Just like his dad! Phoor!

Laughs happily. Pops back out. DAVE stands there, confused but happy.

DAVE I remember. This was a good day.

He still stands there, almost too scared to move. He opens SOPHIE's present. It's the paddling pool. He looks at it, and then notices the lights change and the different sound. Looks at the stereo. The E.P. track has finished again and the 'play-out' groove noise dominates.

DAVE So...what the hell is going on? This is later again...

He's moving about, confused. He goes to his stereo, lifts the arm up to stop the noise. Stands there holding it, and then it begins to dawn on him.

DAVE This has all been to a soundtrack...each track, each different day...?

Thinks.

DAVE 'K. Let's try that again.

He carefully moves the stylus back to the start of the record, puts it down. We hear the sound of a long scratch that leads to the play-out groove sound.

DAVE Woooo!

He grabs the stylus and tries again. Same result.

DAVE Huh. No going back eh?

A moment. He flips the record over. Stops. Looks at it.

DAVE Side two. Just the last two tracks. Where's this taking me? 
Thinking, he goes to put the arm onto the first track. Stops as he remembers.

DAVE 'Five tracks'...'that seem to last a lifetime'...

He looks off towards the room.

DAVE That day we found out...then just before she had...then the half birthday...

Pause.

DAVE $\quad$...a lifetime...

Fearfully he puts the arm back down on the E.P.

DAVE One, 'Confessin' the Blues'.

Music plays. Lights change. Suddenly:

GEMMA (off, angry)....have you heard a single word l've said?!

DAVE Now what's going on?

GEMMA (entering) What's going on Dave, is, I'm tired!

DAVE We were both tired. Tommy wasn't sleeping, we weren't sleeping.

GEMMA Shut up! Stop talking to me like this is part of your stupid book!

DAVE Oh, 'stupid' is the word for it huh? How 'bout 'Pathetic', there's another word for you.

GEMMA You said it, not me.

GEMMA's in the kitchen, fiddling with baby bottles.

DAVE Actually, you say it Gemma, that's a little something we've got to look forward to.

GEMMA Like I look forward to you eventually realising that you are a father, with responsibilities? Turn that bloody thing down!

DAVE I know that! I'm well aware of that 'cos you used to point out my shortcomings in those areas everyday! 
GEMMA

DAVE

GEMMA

DAVE

GEMMA

DAVE

GEMMA

DAVE

GEMMA

DAVE
My fault. Right.

On and on and on. Yeah, a baby, got it. Yeah, get a real job, right. Got one. Yeah, yeah, quality time with you, check, will do. Yeah, keep the music down, come home at a reasonable hour, don't hang out with muso losers, try a different hair style, build a deck, mow the lawns, visit the in-laws, make love once a week, SAVE FOR MY FUCKING RETIREMENT? Where the hell did my life go? Tommy came along and it just INTENSIFIED!

Tommy's fault now.

I... look, listen. I don't want to do this. This was a bad day. We don't have to go there again.

So you get to rant, but not me. Brilliant.

I'm NOT saying anything! I'm not doing this!

Don't have to. It's pretty clear where your head and your heart is.

With you! And Tom -

Bullshit! You want to know where your life went Dave? It went on all your bullshit. You put your headphones on, or you stare into the computer screen, and you go. Hiding inside your bullshit.

I was trying to hang on to a bit of ME! I was being swallowed up by all this.

She stares at him.

DAVE Listen. I don't want this fight. It was too damaging.

GEMMA Too late. Damage done.

She exits. The record sticks. Lights flicker.

DAVE

Gemma...

The stuck record sound drags DAVE's attention to the stereo. He gently nudges the playing arm over the scratch, and the track resumes. GEMMA comes straight 
back on with her coat.

DAVE Hey...

Ignoring him, she walks straight past him into kitchen area.

DAVE $\quad$ Come on now...

She walks straight past him again and into the living room area.

DAVE $\quad$...am I dead again?

She walks straight past him, sighing and shaking her head, into the dining area.

DAVE Oh, ignoring me, very mature.

She stops. Turns to him.

GEMMA I am looking for my bag. Not everything is about you.

He walks straight past her into the kitchen area. Picks up the phone handset. [yes, it has cleverly been replaced] Dials. A cellphone starts ringing. It's in her bag, which is...... under a chair. She looks, finds, and retrieves it. He hangs up.

GEMMA Thank you.

DAVE You're welcome.

GEMMA I'm going out.

DAVE Oh, are you now?

GEMMA You get to spend some time with Tommy.

DAVE Going to see Steve?

GEMMA Don't be pathetic. You're the one in love with Steve, not me.

She exits out the French Doors. He's left 'tearing his hair out'. The E.P. track finishes. He goes to the stereo, lifts the arm. A realisation.

DAVE This is how it happened. Just me and him.

DAVE looks off towards Tommy's room. Looks down at the record.

DAVE This is what I put on. 
He stands very still.

DAVE I play this....and...it's over. I just have to...get through this track.

He looks at the record sleeve.

DAVE 'Around and Around'. Track five. Last track.

He puts the arm down and turns to Tommy's room. Slowly, fearfully he approaches it. Music starts to play. Lighting changes.

DAVE This is that night. Gemma stormed out, and I....I tried to write.... and Tommy started crying and he wouldn't stop. He just wouldn't stop crying, and I.... put on my headphones and turned up the stereo... Iouder and louder, until I disappeared into the music. Until I disappeared...

He moves towards the room as the music on the stereo gets louder and louder, drowning out his words.

Suddenly it reduces to almost no volume. DAVE spins to look at the stereo. SOPHIE stands there holding the volume control, dressed as she was 'in death', a bandage around her left wrist.

DAVE Leave it! Leave that record!

SOPHIE David -

DAVE

DON'T TOUCH MY STUFF!

SOPHIE Listen to me

DAVE I can fix this!

SOPHIE No -

DAVE I HAVE to!

SOPHIE There's no baby.

DAVE What?

SOPHIE The room is empty. 
Music plays. DAVE stares at the doorway to the room.

DAVE No, this is my chance.

SOPHIE See for yourself.

DAVE The track's not over.

SOPHIE Where's your baby?

DAVE He's...

SOPHIE WHERE'S YOUR BABY!

DAVE HE'S DEAD!

Pause.

SOPHIE Did you kill him?

The music volume goes up. There are faint baby's cries mixed into it. Horrified, he looks off to the room. He slams his hands over his ears.

DAVE Aaaaarrgghhh!

SOPHIE DID YOU KILL HIM!

DAVE I DON'T KNOW! I MIGHT HAVE! I MIGHT HAVE KILLED MY BABY! I -

He moves quickly over to the record player.

DAVE - DON'T -

He takes the record off.

DAVE $\quad-$ KNOW!

And smashes the record to pieces.

DAVE (weeping) ...I don't know...don't know...don't...

Pause.

SOPHIE Don't know much do you David? 
He shakes his head.

Pause.

SOPHIE Reckon it's time, don't you?

He nods. SOPHIE touches him lightly on the arm, then goes and stands in the doorway of the French doors.

Enter GEMMA. Sad, lonely. Goes over to the kitchen area. Puts toast in the toaster. Wiping his eyes, DAVE turns to his wife.

DAVE Gem?

She can't see or hear him. He stands there, shaking.

SOPHIE David.

He turns to see SOPHIE in the doorway. He turns back to his wife.

DAVE Gemma, I'm...I....

GEMMA (to toaster) Come on...

DAVE Look. I -

SOPHIE We should go.

DAVE I just want to tell her that I -

SOPHIE Can't hear you.

GEMMA $\quad$...at last... (the toaster pops)

DAVE stands there in the doorway, clutching at straws, but unfortunately, he's dead.

SOPHIE shakes her head. Nothing she can do, she's dead too.

SOPHIE Come on.

GEMMA shakes the toaster, trying to get her toast out. Mumbling to herself. She's alive, and life can be pretty shitty.

GEMMA $\quad$...shouldn't have to be this hard... 
DAVE stands there, then moves to join SOPHIE.

GEMMA takes a knife out of a drawer. Hangs onto the toaster in one hand.

DAVE

Gemma! NO!

She goes to poke the knife in her other hand into one of the toasters slots. DAVE grabs each of her hands and holds them. GEMMA frowns and struggles to bring her hands, the knife and toaster, together. DAVE holds them wide apart.

DAVE Trying to kill yourself? It's still plug-

He realises that this could happen. And if it did...

SOPHIE David. What are you doing?

He allows the hands with the knife and the toaster to slowly come closer and closer together. GEMMA seems fascinated by this.

SOPHIE Dave?

DAVE We can all be together...

The hands get closer. And closer.

SOPHIE Don't do this.

DAVE No! This could work.

The hands get closer.

Suddenly, a baby's crying can be heard on the baby monitor.

DAVE freezes. The hands stop.

DAVE I can hear that!

SOPHIE Hear what?

DAVE I can hear him, Gemma.

They stare at each other. GEMMA dazed, DAVE realising he has to let her go.

DAVE releases GEMMA's hands, and snatches the toaster and knife away from her. 
With nothing left to lose, he plunges the knife into the toaster.

There is the huge electrical sound and flash, and the stage plunges into darkness.

There are strange, echoing sounds washing around. These eventually clarify into GEMMA and SOPHIE's voices.

Lights slowly back up to reveal DAVE comatose on the sofa, with the women around him. The paddling pool with the computer monitor in it, is in the middle of the room.

It's gone midnight. April-ish. Good time for a concert.

GEMMA $\quad$...Dave. Hey, Dave....

SOPHIE $\quad$... Oh my god Gemma, is he..?

GEMMA Come on baby, wake up.

SOPHIE We should call 111 or something.

GEMMA Jeesus Dave, come on, come back to us.

SOPHIE Is he breathing?

DAVE (coming to) Ooooooh, oh hell...

GEMMA Oh, thank you, thank you.

DAVE $\quad$...what, what's goin' on...

SOPHIE You just fucked-up your computer, big time!

DAVE Huh? S-sophie?

SOPHIE Welcome back to the land of the living.

GEMMA(weeping) Oh my god, I thought...

DAVE Gemma?

GEMMA You great big shit, you scared me to death!

DAVE You can see me?

SOPHIE How could we miss it! Nearly took the roof off! 
GEMMA Lie down. Take it easy. You've had a -

DAVE When is this?

GEMMA Dave -

DAVE WHEN IS THIS!

SOPHIE Woooo! Chill, Uncle David.

GEMMA Saturday. We've just been to the Rolling Stones, remember?

SOPHIE You need a, um, drink or something?

DAVE The concert? You mean, it's now?

SOPHIE Think we should get him to A and E Gemma?

DAVE Just give me a minute, hang on.

GEMMA Maybe some water, Sophie.

SOPHIE 'K.

As she moves away to get a glass of water from the kitchen area.

SOPHIE Hey, um, don't worry about that...

DAVE Gemma. Listen to me, listen.

GEMMA It's O.K., it's all O.K.

SOPHIE $\quad$...taking the baby thing...

DAVE I need to tell you, you need to know.

GEMMA Ssshhh, baby.

SOPHIE $\quad$...l'll work something out.

DAVE Tommy. He needed me, and I -

GEMMA Dave, honey, ssshhh, ssshhh.

DAVE I screwed up, Gemma. 
GEMMA

DAVE

GEMMA

DAVE

GEMMA

DAVE
Dave.

I freaked out and put my headphones on and drowned him out!

What? When?

That night.

You told me you didn't hear anything from his room -

You left and I thought 'stuff you' and I turned the music up!

Pause. They look at each other.

DAVE

I'm....so...

GEMMA

You...think it was your fault?

DAVE

...sorry.

A moment.

DAVE

Gem?

GEMMA

I can't remember...if I put him down...on his back.

DAVE

Huh?

GEMMA

I go over and over that night. I left, and...I just don't know.

DAVE

Gemma, I -

GEMMA

Can't get it out of my head. Can't sleep.

DAVE

No -

GEMMA

I left him!

DAVE

With me.

GEMMA

I put him down. It was my fault, not yours.

DAVE

Gemma, no, listen. I stuffed up. 
They stare at each other. A shared realisation.

GEMMA Oh, Dave. Our baby boy...

They cling to each other.

SOPHIE looks on. DAVE sees her. Steps up.

DAVE Sophie. We might be, or we might not be, the worst parents in the world. But. (big breath) If you'll have us...

A moment while SOPHIE takes it in.

SOPHIE Hey, so. You, you're saying...?

DAVE We promise to do our very, very best.

GEMMA looks at DAVE. Sees what she needs.

GEMMA And then some.

DAVE looks at GEMMA, nods.

DAVE $\quad$ And then some more.

They present themselves to her.

SOPHIE Works for me.

The wallphone starts to ring.

DAVE That'll be Steve. Just throw the phone in Sophie's paddling pool. It'll be symbolic.

SOPHIE Of what?

GEMMA goes to the ringing phone.

DAVE You tell me.

She answers the phone.

GEMMA(on phone) Splash.

She hangs up the phone. 
DAVE Hey, you're funny.

SOPHIE Um. How about some music? I can plug my ipod into your stereo.

GEMMA Sorry Sophie -

SOPHIE I've got some great indie stuff.

GEMMA Around here it's strictly classic roc -

DAVE Why not? Whack it on, Sophie.

He holds his hand out to his wife.

DAVE Let's try something new.

She takes his hand.

DAVE See what happens.

They decide there and then to never let go.

SOPHIE goes to the stereo, and plugs new technology into the classic system.

She turns to them.

SOPHIE You guys rock.

Music plays, lights fade, as it is, in fact...

THE END 